\title{
The Informing Science Institute: The Informing System of a Transdiscipline
}

\author{
William F. Murphy, Jr. \\ University of South Florida, Tampa, Florida, USA
}

infosys@creativeresearchllc.com

\begin{abstract}
The Informing Science Institute (ISI) is an informing system, designed using informing science principles, for the express purpose of informing researchers who study problems related to informing. The ISI provides several informing channels, including peer reviewed journals, conferences, books, and outreach activities. The ISI seeks to resonate with university researchers to provide rigorous and relevant information about informing research. The ISI prints and electronically publishes peer reviewed scientific literature concerning the transdiscipline of informing science at no charge to the authors or readers, with open access for all, in eight academic journals. This paper discusses what informing science is, the need for a transdiscipline, the channels of the ISI informing system, and describes the clients of the ISI. This paper also analyzes the authors, institutions, and countries of origin for every ISI paper published between 1998 and 2009, as well as reporting interviews with the Editor-In-Chiefs of each ISI journal.
\end{abstract}

Keywords: Informing Science Institute, open access, information systems, transdiscipline, informing systems

\section{Introduction}

Academic research today is often conducted through the myopic lens of one discipline or another, using the approaches favored by a specific discipline, and with the results published in journals dedicated to and commonly only read by one discipline. There are many complex problems found in the real world, however, that cannot be solved without considering the problem from several viewpoints. The Informing Science Institute allows research to be published that considers multiple disciplinary viewpoints and approaches to discussing issues related to informing.

Informing science is a philosophical research approach that encourages researchers to step out of their departmental research silos, collaborate, and learn from each other when researching systems that are designed to inform (Cohen, 2009a). The Informing Science Institute (ISI) is the organizing body founded to advance informing science research, collaboration, and mentorship. In the decade since its founding, the ISI developed a large academic membership and an active pub-

Material published as part of this publication, either on-line or in print, is copyrighted by the Informing Science Institute. Permission to make digital or paper copy of part or all of these works for personal or classroom use is granted without fee provided that the copies are not made or distributed for profit or commercial advantage AND that copies 1) bear this notice in full and 2) give the full citation on the first page. It is permissible to abstract these works so long as credit is given. To copy in all other cases or to republish or to post on a server or to redistribute to lists requires specific permission and payment of a fee. Contact Publisher@InformingScience.org to request redistribution permission. lishing platform. For example, since its inception, it has published approximately 1,000 articles by over 1,000 authors from over 500 universities all across the globe (See http://informingscience.org/journals.php for listing of all journal articles.)

In the present paper, the ISI is described as an applied instance of an informing 
system. Key characteristics of the system are as follows:

- Interdisciplinary Community of Clients: Membership of the ISI includes researchers from information science, management information systems, instructional technology, education, communication, biology, cognitive sciences, and other disciplines, all collaborating in studying problems related to informing.

- Diverse Informing Channels: The institute provides several channels of communication to its clients, including conferences, books, outreach activities, and 8 peer-reviewed scientific research journals that allow researchers to obtain peer review and publishing of their articles at no charge.

- Global Community of Informers: The institute's publications boast an international group of contributors, guided by a variety of epistemologies, and facilitated by the international flavor of its conferences.

We begin by considering the definition of an informing system. Then we describe how the elements of the ISI fit into this definition. The clients of the ISI are described, followed by a description of the informing channels the ISI employs, such as journals, books, and conferences. We conclude with an examination of some of the challenges and opportunities that face the ISI in the future.

\section{The Definition of an Informing System}

Cohen (2009a) specifies that the informing science framework has three components that must be present in an Informing System: the informing environment, the delivery system, and the taskcompletion system:

- Informing Environment. The informing environment is analogous to the sender and encoder in the Shannon and Weaver (1949) communication model. Unlike the communication model, the informing science framework considers the informing environment at three levels of abstraction. These three levels are (a) the instance (using a system that is in place), (b) the creation of new instances of informing (to the organization or any of its components), and, at the highest level, (c) the creation of new designs for informing.

- Delivery System. The delivery system refers to the use of information technologies (computing, communications, and so on) that support the implementation of the informing environment. Information technologies are not limited to computing. Data communication includes video and voice, and even personal contact when it is augmented through planned communication.

- Task-Completion System. The driving force behind the creation of informing environments and delivery systems is that a task needs to be accomplished. The task defines what information is needed. This task completion component typically involves a person who has a job at hand. It corresponds to the decoder - receiver components in the communications model.

○ The task completion system is the sole component that defines the difference among various academic disciplines that comprise informing science (Cohen, 1999/2009b, p. 15). While all of the these disciplines have the need to inform clients, they are not disciplines of informing science. Rather, they are client disciplines of informing science.

Figure 1 below shows Cohen's (2009a) representation of an informing system. In the simplest informing systems, these components may map directly to a sender/informer, a single channel 
and client. In real world settings, however, such systems are rarely so straightforward. For example, participants may play multiple roles within the system (e.g., informer and client). Multiple multi-directional channels may be present. Informing may involve multiple clients and/or tasks. As Gill discusses (2009b), the channel as well as the content of the messages can affect the usefulness of the informing system, and consequently the usefulness of the system determines whether or not senders and receivers of messages will actually use the system. We now look at some of the key elements of the informing system that has developed around the ISI.

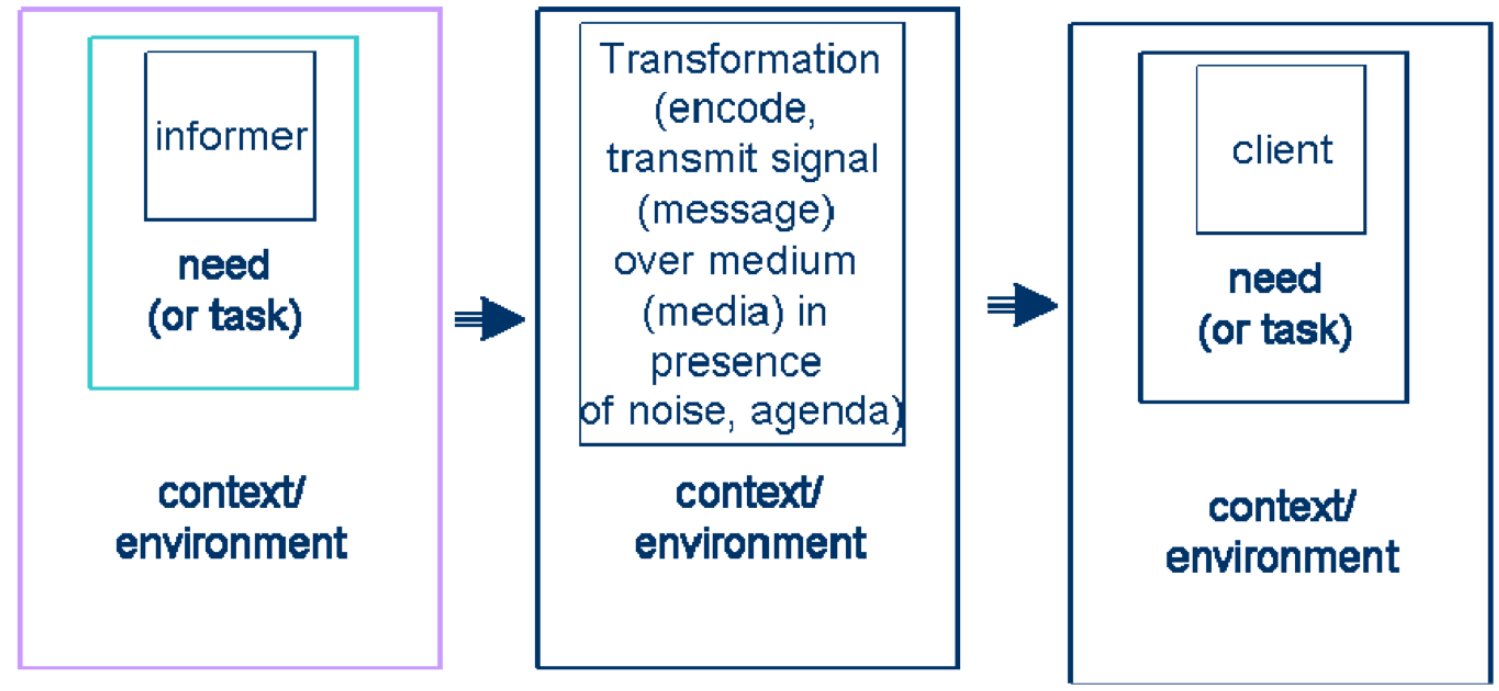

Figure 1 from Cohen (2009a) illustrates the framework for informing systems.

\section{The ISI as an Informing System}

Gill and Bhattacherjee (2009b) identify four characteristics that should be present for the informing science approach to be considered the appropriate approach:

- $\quad$ The client has an unaddressed set of problems (p. 41)

- Serving the client provides access to resources (p. 41)

- The members of the discipline have the expertise to address the client's unaddressed problem (p. 42)

- One or more resonant communications channels exist, or can be created (p. 42)

If we consider the Informing Science Institute as an instance of informing system, using the framework of informing science as a model, we see that:

- The ISI is a sender of messages, disseminating published research to the consumers of its research.

- The ISI journal editors, who mentor the potential authors, are also senders of messages to researchers who wish the ISI to publish their research.

- The ISI defines and refines its informing environment, primarily through the founder and fellows, who guide the direction of activities and publications.

- There are several channels that are maintained by the ISI, including conference, books, journals, outreach activities.

- Clients of the ISI include researchers, consumers of research, and conference attendees.

Refer to Figure 2 for a diagram of the Informing Science Institute as an informing system. 


\section{Informing Science Institute Informing System}

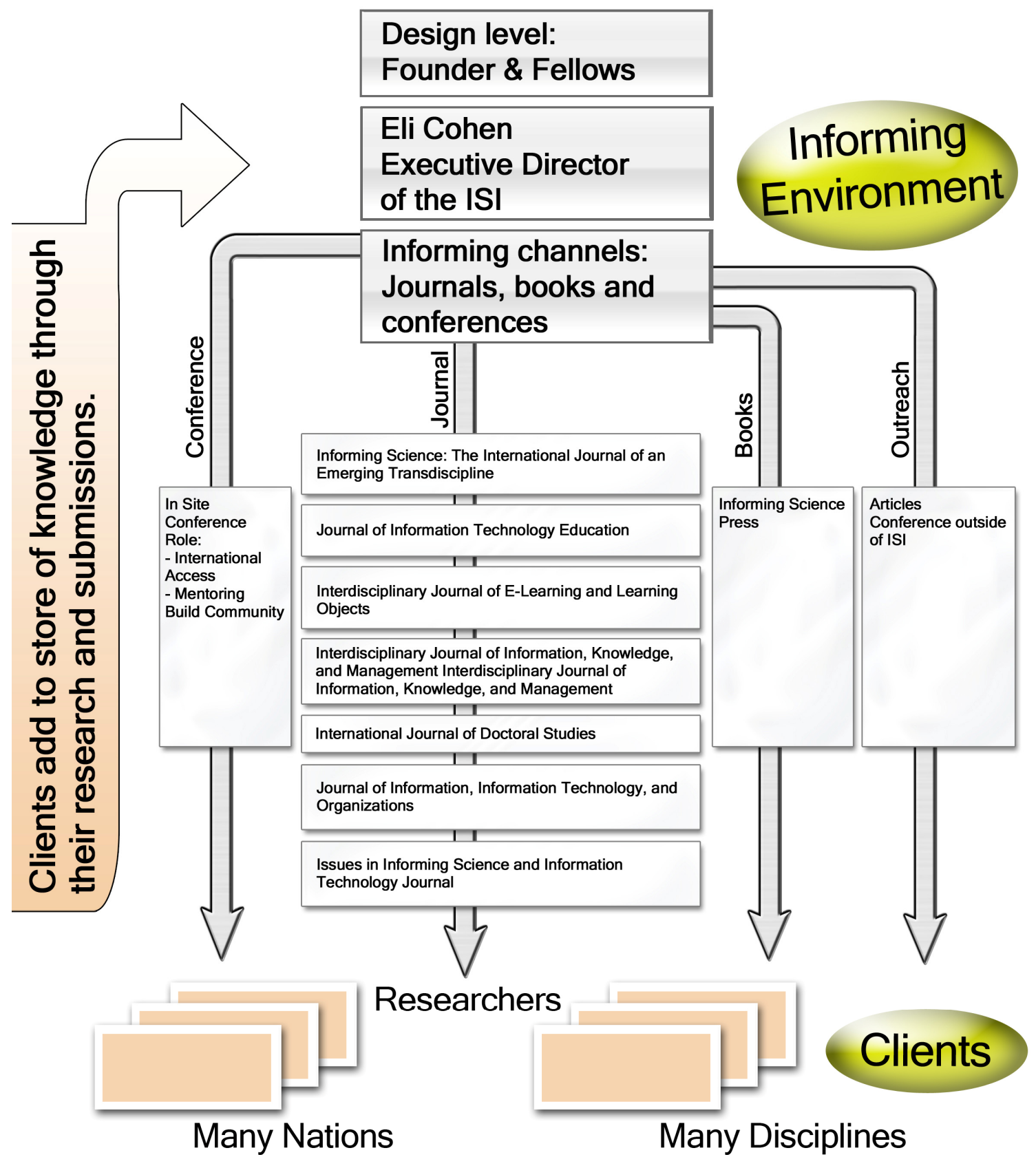

Figure 2: Informing Science Institute as an Informing System 


\section{The ISI Clients}

The ISI targets a set of clients that is diverse in two important respects: (1) they come from many disciplines, and (2) they come from many nations. In order to serve these clients effectively, the research being communicated must meet three criteria: rigor, relevance, and resonance. The ISI attempts to control the rigor of its communications by relying on the peer review model used by other academic journals. Before research is published, it is vetted and edited by experienced researchers who are familiar with the subject being researched. Reviewers of manuscripts include those who have successfully been published in journals and hopefully have some familiarity with the author's topic or methodology or interest. Authors are provided with constructive feedback through this developmental review process (Informing Science Institute, 2011).

With respect to relevance, all the members of the ISI have a common interest in studying problems related to informing. All of the research published and discussed is expected to have some theme that relates to the problems of informing. Individual instances of research might take an instructional technology approach, or may be looking at a problem in business information systems, or may be concerned with communications or other philosophical approaches. But, the common thread of relevance to the members of the ISI is that all the research being considered has some relation or connection back to problems and areas related to informing.

The third criterion, resonance, is of particular importance when serving a diverse clientele such as the ISI membership. Gill (2009a, p. 239) describes resonance as "the ability of the research message to move through available channels to the client and, subsequently, to impact that client's mental models." To achieve such resonance within the informing system presented in Figure 2, the ISI paid particular attention to these broadly defined needs:

- The need to get their research published,

- The need to overcome barriers to readers accessing their research once published,

- The need to be mentored by more experienced researchers,

- The need to be exposed to methods beyond their own disciplinary approaches,

- The human need to belong to a community with common goals and interests and all that implies.

Key features of the system design intended to meet these needs are now described.

\section{Open Access}

The ISI does not charge authors to publish, nor does it charge anyone for electronic copies of its full text articles. The goal of the institute is the accumulation and dissemination of quality scientific research to as wide an audience as possible (Gill \& Cohen, 2009). With many of its clients coming from poorer nations and from universities without large research budget, an open access model serves to remove financial barriers that would prevent researchers from publishing their research or that could prevent potential consumers of that research from accessing it. This open publishing approach is in stark contrast to the commercial traditional publishing approach followed by many other academic journals.

Herb (2010) lists the following as the common perceived advantages of open access academic journals:

- Open access accelerates scientific communication.

- Open access removes financial barriers to sharing knowledge.

- Open access reduces social barriers to accessing knowledge. 
- Open access facilitates participation from all levels.

- Open access reduces across geographic, international, and economic barriers.

Open access journals tend to help "poorer" countries have access to scientific literature that might otherwise be beyond their reach. "Free online availability 'is not a huge driver of science in the first world, but it shapes parts of science in the rest of world,' Evans told The Scientist" (Dolgin, 2009). Thus, the open access policy of ISI is closely tied to its international clientele, now discussed.

\section{International}

The ISI makes a particular effort to support a global clientele. As illustrated in Figure 3, its contributors come from not only well-established research centers, such as North America, Australia, and Western Europe, but also from regions that are typically underrepresented, such as Africa, the Middle East, and Eastern Europe.

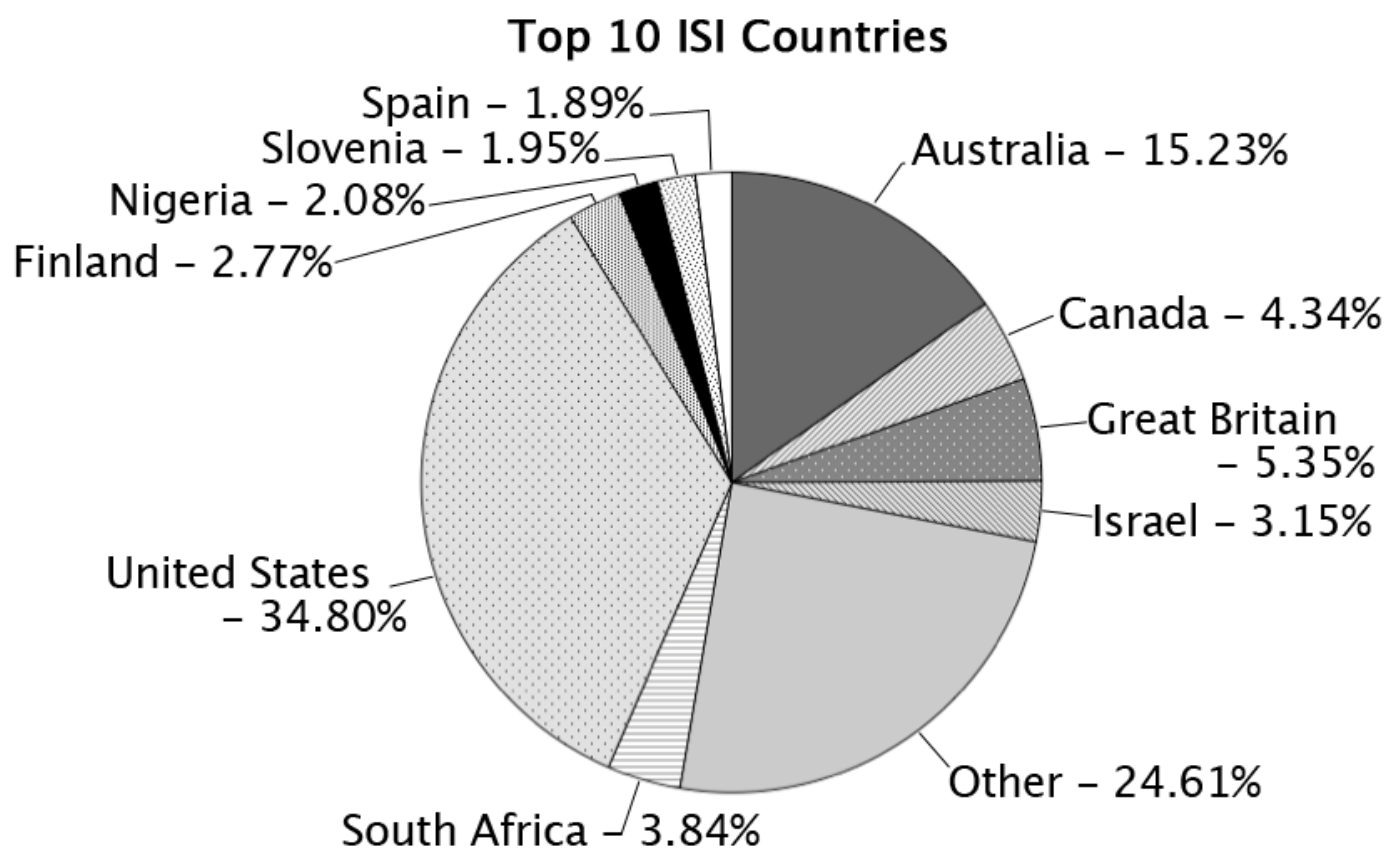

Figure 3: The percentage of articles with authors representing various countries in all ISI journals from 1998 through 2009

To provide a basis for comparison, Figure 4 presents the percentage of authors outside of the U.S. contributing to ISI academic journal publications compared to equivalent percentages for the two leading journals in MIS: Management Information Systems Quarterly (MISQ) and Information Systems Research (ISR) articles over the same time period. 


\section{$\%$ of Authors with International Authors from 1998-2009}

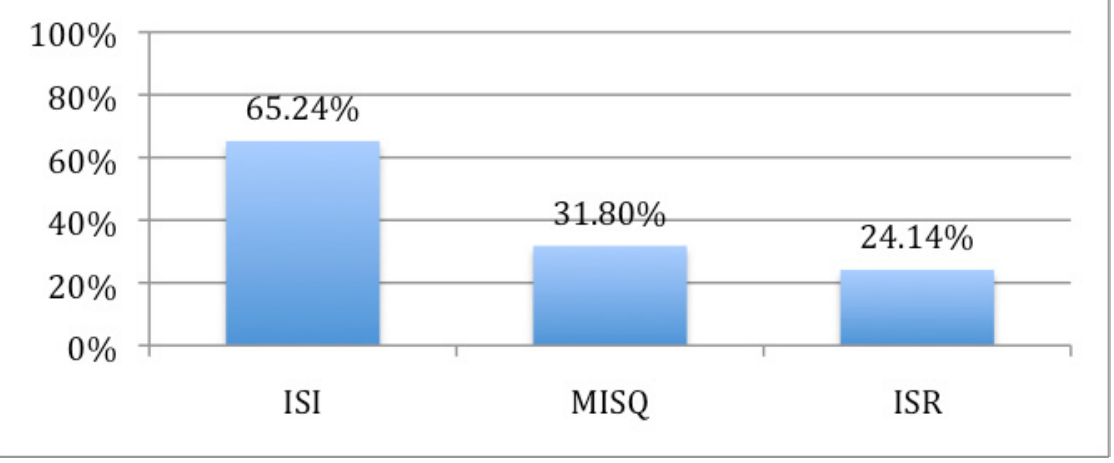

Figure 3. Percentage of ISI journal articles with authors affiliated with universities outside the United States from 1998-2009.

(From data the author gathered by inspecting all articles published in each ISI journal, MISQ, and ISR from 1998-2009.)

\section{Multidisciplinary Community}

A driver of diversity for ISI publications is the transdiscipline approach. Cohen (2009a) states that the informing science design framework is transdisciplinary and is a common design and analysis framework for any system whose purpose is to inform. "The informing science as a discipline emerged as a result of the observation that many disciplines like education, library science, information systems were studying the movement of information between senders and receivers in ways that were far more similar than they were different" (Gill \& Bhattacherjee, 2009b p. 22). Cohen (2009a) asserts that transdisciplines such as statistics and informing science may be applied to enhance research activities in many disciplines. By freeing the research process from discipline specific constraints, researchers can focus on producing quality research rather than on the academic-political limitations of the research they produce.

The problem often encountered with multidisciplinary research is the absence of outlets specializing in such research in an environment dominated by disciplinary researchers. Academic researchers who would like to advance their careers in the current tenure-granting system have every reason to publish in certain favored journals, cite those articles, and hope that other authors who publish in the favored journals cite them as well:

- Researchers are motivated and rewarded based on recognition in the research community for published work (Hagstrom, 1965; Meadows, 1974).

- Promotion, tenure, grants, salary, and positions in academia are all determined by the citation driven recognition from other researchers (Cohen, 2009a; Cole \& Cole, 1973; Zuckerman \& Merton, 1971).

- Citations have more influence on academic salary than how much research an academic does or what their experience is (Hamermesh, Johnson, \& Welsbrod, 1982).

In the absence of a multidisciplinary community, the extrinsic rewards for conducting such research are likely to be very limited. Thus, building such a community around informing has been a central goal of ISI. The Informing Science and IT Education (InSITE) conferences play a par- 
ticularly important role in building such a community. An important feature of these conferences is the associated study missions, which are designed to build the trust relationships that benefit long-distance research collaboration.

Another key aspect of the ISI community is the presence of highly active members and institutions. Such activity, as illustrated in Table 1, demonstrates a strong commitment to informing science research. Notably, three of the four most published authors in the field have taken on leadership roles in the ISI, agreeing to serve as Fellows of the ISI (Gill, Buzzetto-More, and Koohang).

Table 1. Frequently published authors and institutions across ISI journals.

\begin{tabular}{|l|c|c|}
\hline Most Published Authors & Country & Number \\
\hline T. Grandon Gill & USA & 21 \\
\hline Azad Ali & USA & 11 \\
\hline Nicole A. Buzzetto-More & USA & 11 \\
\hline Alex Koohang & USA & 10 \\
\hline Raafat George Saade & CAN & 10 \\
\hline Grace Tan & AUS & 9 \\
\hline Frederick Kohun & USA & 8 \\
\hline Arthur Tatnall & AUS & 8 \\
\hline Anne Venables & AUS & 8 \\
\hline Bill Davey & AUS & 8 \\
\hline
\end{tabular}

\begin{tabular}{|l|c|c|}
\hline Most Published Institutions & Country & Number \\
\hline Victoria University & AUS & 35 \\
\hline University of South Florida & USA & 21 \\
\hline California State University & USA & 17 \\
\hline University of Wisconsin & USA & 17 \\
\hline Open University of Israel & ISR & 15 \\
\hline Pennsylvania State University & USA & 14 \\
\hline Purdue University & USA & 14 \\
\hline Deakin University & AUS & 13 \\
\hline Edith Cowan University & AUS & 13 \\
\hline Griffith University & AUS & 13 \\
\hline
\end{tabular}

\section{Researchers Mentoring Other Researchers}

The ISI is dedicated to providing mentoring services to other researchers. The combination of open access and the various channels facilitates mentoring communications being delivered to the clients of the ISI.

The Founder of the ISI emphasized mentoring as one of the two guiding principles of the Institute, "As an organization, it is guided by two principles: setting knowledge free through making all of its publication available free of charge online, and embracing mentorship, that is, colleagues helping colleagues learn how to improve" (Gill \& Cohen, 2009, p. 2).

Mentoring is, in many ways, another informing process where the Founder and Fellows mentor the Editors-In-Chiefs of the journals, the Editors-In-Chiefs mentor the Editors, the Editors and reviewers mentor the authors, and the authors inform their readership and everyone else with their research.

Dr. Gill, the Editor-In-Chief of the journal Informing Science (InformSciJ) had the following comments on the importance of mentoring in his Open Letter (Gill, 2009c):

- "What goes on behind the scenes - during the mentoring and encouragement that occurs during the review process, during the conference sessions where we describe how to write for the journal, over the course of editor interactions with potential authors - are equally important parts of knowledge sharing." ( p. v)

- "I view my main role at InformSciJ as one of being a mentor to the editors; I also anticipate that they will also serve as mentors to me on a regular basis." (p. ix)

- One of the Editors three primary duties is: "Mentoring the authors to become even better at writing their research papers." (p. ix) 
Mentoring is a type of informing--specifically, active informing--where the purpose of the informing is to direct the receivers to take a specific action: to make changes to their research publications so that those papers are more publishable, more readable, and generally better. In fact, the sender and the receiver both learn from this process. These types of bi-directional informing processes not only improve the products of the informing system, but also are processes that improve the informing system itself.

\section{The ISI Channels}

As Cohen (2009a) pointed out, research needs to be published to reach the largest number of consumers, and academic researchers are generally incentivized for research that is published in journals. Therefore, if an informing system is to have academic researchers as clients, it is likely to need to offer a journal as a channel in order to communicate with resonance to that group. However, Cohen (2009a) also pointed out that face-to-face and interpersonal interactions facilitate building trust and sense of the community of clients the informing system serves. Accordingly, the institute offers conferences as another channel to help build trust and facilitate concepts being transferred between members from different disciplines. Whereas its journals focus on publishing articles that relate to the specific mission of each journal, the institute also publishes books that compile articles from across the journals related to specific themes that may be covered by several journals within the ISI. So, again books are another way of packaging information that is rigorous, relevant, and resonant to the reader/researcher.

\section{Journals of the ISI}

There are eight journals within the Informing Science Institute. Refer to Table 2 for the list of journals, the year the journal was founded, and how many articles, authors, and institutions have been published in each journal through 2009.

Table 2. Journals of the Informing Science Institute

\begin{tabular}{|l|l|c|c|c|c|}
\hline \multicolumn{1}{|c|}{ Title } & Specialization/Mission & $\begin{array}{c}\text { Authors } \\
\text { through } \\
\mathbf{2 0 0 9}\end{array}$ & $\begin{array}{c}\text { Articles } \\
\text { through } \\
\mathbf{2 0 0 9}\end{array}$ & $\begin{array}{c}\text { Institutions } \\
\text { through } \\
\mathbf{2 0 0 9}\end{array}$ & $\begin{array}{c}\text { Year } \\
\text { Founded }\end{array}$ \\
\hline $\begin{array}{l}\text { 1. Informing Science: } \\
\text { The International } \\
\text { Journal of an Emerg- } \\
\text { ing Transdiscipline }\end{array}$ & $\begin{array}{l}\text { The flagship journal } \\
\text { of the ISI, focusing } \\
\text { on theory and prac- } \\
\text { tice of informing }\end{array}$ & 191 & 122 & 105 & 1998 \\
\hline $\begin{array}{l}\text { 2. } \\
\text { Journal of Information } \\
\text { Technology Educa- } \\
\text { tion }\end{array}$ & $\begin{array}{l}\text { Serves the informa- } \\
\text { tional technology } \\
\text { education audience }\end{array}$ & 407 & 205 & 196 & 2002 \\
\hline 3. $\begin{array}{l}\text { Interdisciplinary } \\
\text { Journal of E-Learning } \\
\text { and Learning Objects }\end{array}$ & $\begin{array}{l}\text { Considers instruc- } \\
\text { tional technology } \\
\text { issues of informing }\end{array}$ & 189 & 85 & 82 & 2005 \\
\hline 4. $\begin{array}{l}\text { Interdisciplinary } \\
\text { Journal of Informa- } \\
\text { tion, Knowledge, and } \\
\text { Management }\end{array}$ & $\begin{array}{l}\text { Considers informa- } \\
\text { tion and technology } \\
\text { in organizations }\end{array}$ & 78 & 37 & 43 & 2006 \\
\hline
\end{tabular}




\begin{tabular}{|c|c|c|c|c|c|}
\hline $\begin{array}{l}\text { International Journal } \\
\text { of Doctoral Studies }\end{array}$ & $\begin{array}{l}\text { Considers issues with } \\
\text { informing doctoral } \\
\text { students }\end{array}$ & 34 & 19 & 20 & 2006 \\
\hline $\begin{array}{l}\text { 6. Journal of Informa- } \\
\text { tion, Information } \\
\text { Technology, and Or- } \\
\text { ganizations }\end{array}$ & $\begin{array}{l}\text { Uses a balanced ap- } \\
\text { proach to informa- } \\
\text { tion, technology, and } \\
\text { organizational con- } \\
\text { text }\end{array}$ & 58 & 32 & 31 & 2006 \\
\hline $\begin{array}{l}\text { 7. Issues in Informing } \\
\text { Science and Informa- } \\
\text { tion Technology Jour- } \\
\text { nal }\end{array}$ & $\begin{array}{l}\text { Covers IT in all other } \\
\text { disciplines }\end{array}$ & 542 & 392 & 226 & 2004 \\
\hline 8. Informing Faculty & $\begin{array}{l}\text { Now a passive re- } \\
\text { pository }\end{array}$ & 13 & 10 & 2 & 2006 \\
\hline
\end{tabular}

\section{Informing Science: The International Journal of an Emerging Transdiscipline - http://Inform.NU}

Informing Science: The International Journal of an Emerging Transdiscipline (InformSciJ) (2010) seeks to provide an understanding of the complexities in informing clientele regarding fields from information systems, library science, journalism in all its forms to education. These fields, which have been developed and researched independently, are evolving to form a new transdiscipline, informing science. This journal publishes articles that provide insights into informing clients. Authors may use knowledge from a variety of fields including but not limited to engineering, computer science, education, psychology, business, anthropology, and such.

\section{Key Statistics}

InformSciJ was founded in 1998. Since its inception through 2009, it published 122 articles, submitted by 191 authors from 105 institutions.

Key statistics relating to authorship and international contributions are presented in Table 3 and Figure 5 (see the Appendix for explanation of data collection for Tables 3-9 and Figures 5-11).

Table 3. Frequently published authors and institutions: Publishing in Informing Science

\begin{tabular}{|l|c|c|}
\hline $\begin{array}{c}\text { Most Published } \\
\text { Author }\end{array}$ & Country & $\begin{array}{c}\text { Num- } \\
\text { ber }\end{array}$ \\
\hline T. Grandon Gill & USA & 9 \\
\hline Petter Gottschalk & NOR & 5 \\
\hline Peter M. Bednar & SWE & 4 \\
\hline Alex Koohang & USA & 3 \\
\hline Christine Welch & GBR & 3 \\
\hline Chris Cope & AUS & 3 \\
\hline Terry J. Smith & USA & 2 \\
\hline Nitza Geri & ISR & 2 \\
\hline Yair Levy & USA & 2 \\
\hline Timothy J. Ellis & USA & 2 \\
\hline
\end{tabular}

\begin{tabular}{|l|c|c|}
\hline \multicolumn{1}{|c|}{ Most Published Institution } & Country & Number \\
\hline University of South Florida & USA & 9 \\
\hline Norwegian School of Management & NOR & 6 \\
\hline Lund University & SWE & 5 \\
\hline Pennsylvania State University & USA & 5 \\
\hline University of Wisconsin & USA & 5 \\
\hline California State University & USA & 4 \\
\hline Central Queensland University & AUS & 4 \\
\hline Edith Cowan University & AUS & 4 \\
\hline Informing Science Institute & Int'l & 4 \\
\hline University of Twente & NLD & 4 \\
\hline
\end{tabular}




\section{Top 10 InformSciJ Countries}

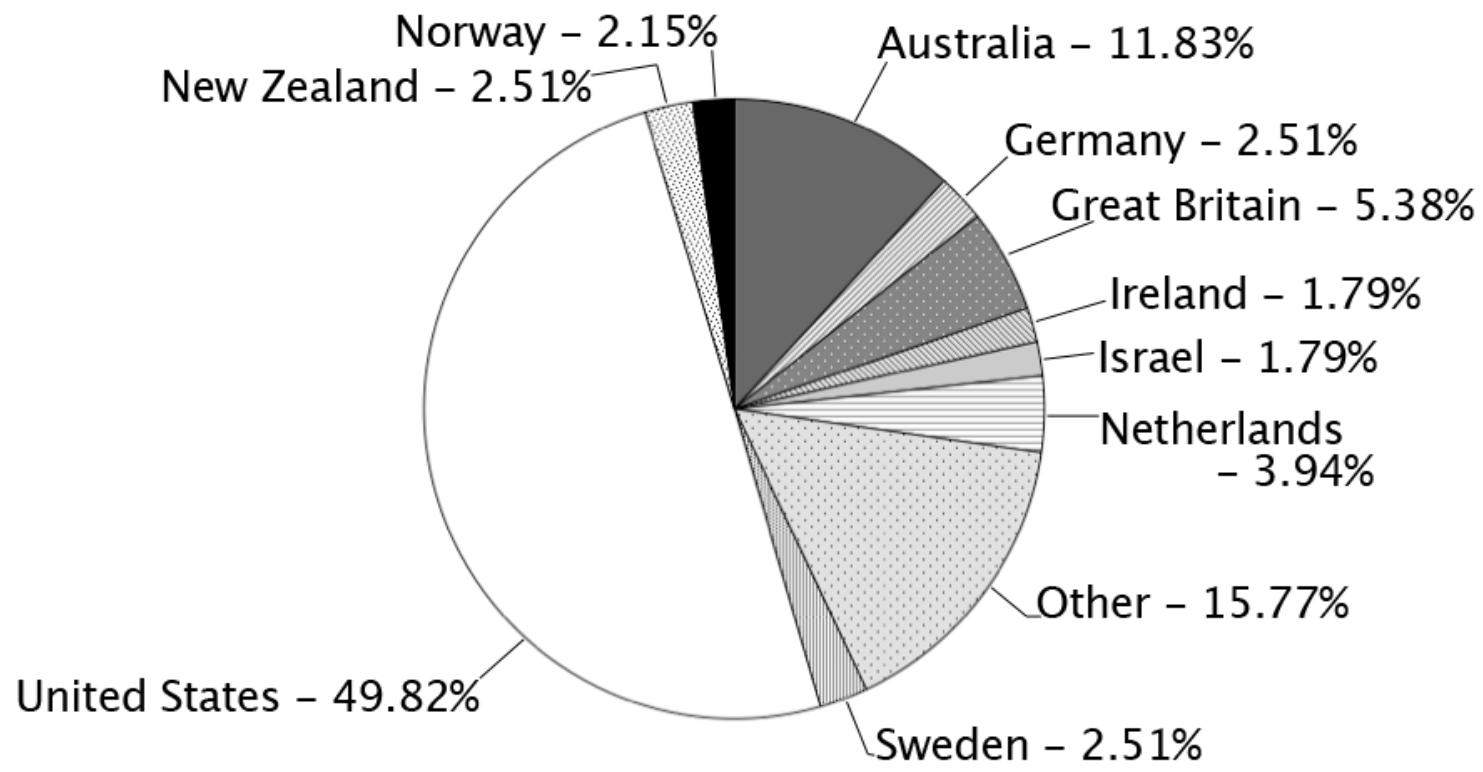

Figure 5 Represents the percentage of articles with authors representing various countries in InformSciJ through 2009

\section{An Interview with T. Grandon Gill, Editor-In-Chief of InformSciJ}

\section{Can you tell me a little about the history of the journal?}

Informing Science was the first journal launched by the Informing Science Institute. Some of the articles in the earliest journals got quite a few references as they defined the transdiscipline. The first Editor-in-Chief was Eli Cohen, who served through 2006. It was then turned over to Scott Lloyd. It was turned over to me around 2009. It has a small but enthusiastic following, leading to it being rated as an A journal in Germany. If you take a look at the broader picture, we are not really an IS journal. From an MIS perspective, we are all over the map; that is one of the challenges of a being transdisciplinary journal.

\section{What are your main aspirations for the journal?}

My aspiration is for us to bring together contributions from several disciplines. That means we have to be very open minded-because what constitutes research varies significantly between disciplines. On the other hand, I still have to be very specific that submissions need to have something to do with informing. However, it is not my intention to make the journal a prestige journal with a low acceptance rate. First, I think it is a mistake to equate low acceptance rates with quality. Second, it is hard to find reviewers who can make rigorous judgments outside of their research area. So, what I see Informing Science becoming is a journal that accepts quality submissions with clear explanations of what is being done, and we can be adventurous about what we accept so long as it is about informing and it is generally good. I would like the journal to be a meeting ground between the disciplines.

\section{What readership is the journal serving?}

The principal readership we serve is members of the Informing Science Institute from many disciplines, particularly education, such as Instructional Technology, business disciplines, such as 
MIS, information science, and occasionally philosophy and other disciplines. This meeting ground facilitates collaboration across disciplines.

What areas of research within informing science do you feel to be the most promising?

What captures my interest most is how the process of informing changes when we deal with the routine versus the non-routine.

Why are certain areas of informing science poorly understood or under recognized?

There is an assumption - because the articles we have covered in the past - that we are an instructional technology group. Researchers outside the field do not realize the breadth of what we are trying to do.

\section{Where does this journal sit within the informing science transdiscipline?}

This is the flagship informing science journal, but not the most highly ranked. The Journal of IT Education [JITE], for example, is better-known and more highly ranked. A key advantage of JITE is the fact that it is more clearly associated with the MIS/IT disciplines. Informing Science is where you want to go if you want to publish an article on informing science rather than an article on something more specifically MIS or education focused.

Are there any disadvantages to being a journal within the informing science transdiscipline?

Because Informing Science does not fit easily within the other disciplines, we aren't likely to gain a high ranking. Naturally, this can affect an academic's incentives to publish with us. And our transdisciplinary nature makes it a challenge to get reviewers who can review the diverse papers we get.

\section{Who are the practitioners served by your journal?}

When you are dealing with a transdiscipline, the practitioners are going to be different, i.e., people who are outside of the field of the author. We want to inform our audience outside of their area of research to help tear down research silos. Right now we act as information exchange between disciplines.

\section{How do you try to balance the needs of students, researchers, and practitioners?}

The key needs of these three groups are met by trying to write in such a manner that a reader from outside the author's discipline can understand what the author is saying. Otherwise it is almost impossible for non-insiders to read and understand the research. Clarity is the thing we are most interested in achieving to balance those needs.

\section{What characteristics in a submission are your reviewers looking for?}

We frequently get quite a spread among the reviewers. We definitely want a clear link to informing. Furthermore, we always value clarity of thought and expression and logical flow.

\section{How do you foresee your journal evolving in the future?}

I am trying to increase the visibility of informing science within my discipline (MIS), and I am hopeful key submitters from other disciplines do the same.

Does your journal tend to favor positivism versus interpretivism, or quantitative study versus qualitative? Why?

I will publish anything if it is of reasonable quality. 


\section{How did you become interested in informing science?}

The writing of Eli Cohen and attending an InSITE conference made me interested in studying informing. I submitted some papers and was "hooked." It struck me as a better way to approach many of the problems I was researching. As a result of my numerous submissions, I was asked to be an Editor.

\section{What do you like the most and the least about being an Editor?}

The Editors have great impact on what does or does not go into journal. However, routinely going through submissions and having to reject other peoples' work is not fun.

Can you give me one example where an article published in your journal may have made a measurable impact in the broader world?

Any answer I give would be speculative. But, in a transdiscipline, we are interested in exerting impact on other disciplines. Practice is not our target audience, as we are more involved with trying to tear down research silos within academic disciplines. We are still a relatively young journal and young field, so I would hesitate to make broad speculative claims without substantiation.

\section{Journal of Information Technology Education - http://jite.org/}

As described by the Journal of Information Technology Education (2010) (JITE), its mission is to do the following: improve IT education by publishing quality articles of the best practices and other topics to improve IT education; provide the reader with a variety of articles to include primary, action, and secondary research; provide a constructive review process; be the most authoritative journal on IT education; acknowledge the diversity of teaching and learning around the world.

\section{Key Statistics}

JITE was founded in 2002. Since its inception through 2009, it published 205 articles, submitted by 191 authors from 105 institutions.

Key statistics relating to authorship and international contributions are presented in Table 4 and Figure 6 (see Appendix for explanation of data collection for tables 3-9 and Figures 5-11).

Table 4. Frequently published authors and institutions: Publishing in Journal of Information Technology Education

\begin{tabular}{|l|c|c|}
\hline Most Published Author & Country & Number \\
\hline Anne Venables & AUS & 6 \\
\hline Grace Tan & AUS & 5 \\
\hline Han Reichgelt & USA & 4 \\
\hline Nicole A. Buzzetto-More & USA & 3 \\
\hline Matti Tedre & TZA & 3 \\
\hline Azzedine Lansari & DZA & 3 \\
\hline Akram Al-Rawi & USA & 3 \\
\hline Mark Stansfield & GBR & 3 \\
\hline Thomas Connolly & GBR & 3 \\
\hline Elsje Scott & ZAF & 3 \\
\hline
\end{tabular}

\begin{tabular}{|l|c|c|}
\hline Most Published Institution & Country & Number \\
\hline Victoria University & AUS & 11 \\
\hline Purdue University & USA & 7 \\
\hline Pennsylvania State University & USA & 6 \\
\hline Griffith University & AUS & 5 \\
\hline University of Capetown & ZAF & 5 \\
\hline California State University & USA & 4 \\
\hline Concordia University & CAN & 4 \\
\hline Georgia Southern University & USA & 4 \\
\hline Monash University & AUS & 4 \\
\hline $\begin{array}{l}\text { Queensland University of } \\
\text { Technology }\end{array}$ & AUS & 4 \\
\hline
\end{tabular}




\section{Top 10 JITE Countries}

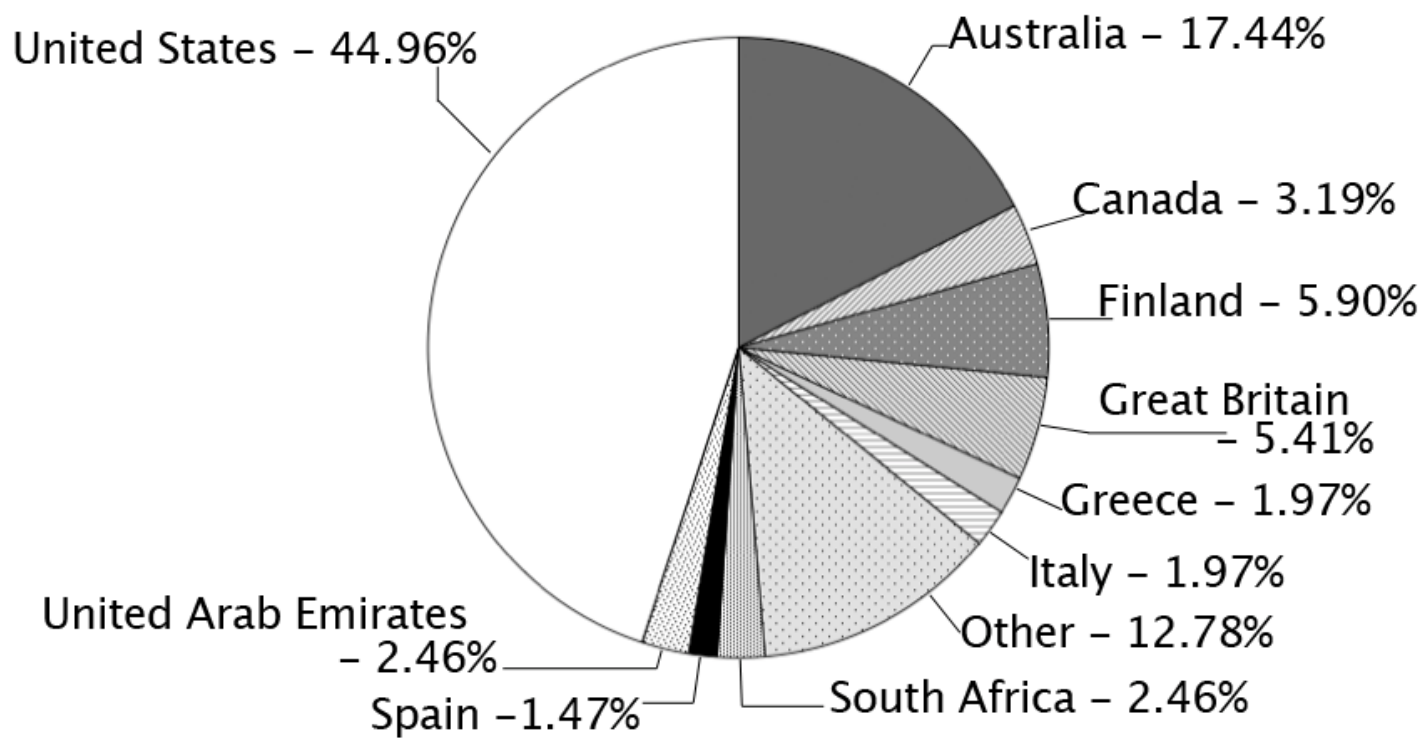

Figure 6: Percentage of articles with authors representing various countries in JITE through 2009

\section{An Interview with Linda Knight, Editor-In-Chief of JITE}

\section{Can you tell me about the history of the journal?}

The Journal of Information Technology Education published its first issue in January of 2002. Eli Cohen was the force behind it and I was one of 5 initial editors reviewing papers for the journal. As the journal and the Informing Science Institute grew, Eli transitioned the role of Editor-inChief to me around January 2005.

\section{What are your main aspirations for the journal?}

I would like JITE to be widely recognized as the top quality IT Education journal. We are close to, if not at this point, now. I would also like JITE to be the most widely read IT education journal internationally (I believe the statistics show we clearly have achieved this). I would like us to continue to uphold and extend the major principles of the Informing Science Institute. These include mentoring authors by providing rapid and high quality feedback, as well as making research freely available within the research community.

\section{What readership is the journal serving?}

We are the Journal of Information Technology Education, so our primary readership is faculty members who either are teaching technology related areas or using technology in their classrooms.

\section{What areas of research within your journal do you feel to be the most promising?}

The area that is expanding at record speed right now is anything having to do with online learning or technology enhanced education. 


\section{Why are certain areas of informing science poorly understood or under recognized?}

JITE is not focused solely on informing science so this question does not apply directly to us; our journal is focused on the combination of information technology and education. Certainly one component of education is informing, and to the extent that we can leverage our knowledge of informing within the educational community, learning will be enhanced.

\section{Where does this journal sit within the informing science transdiscipline?}

Informing science focuses on the use of technology for informing, and this journals' focus is on the education component of informing.

\section{Are there any disadvantages to being a journal within the informing science transdisci- pline?}

No, for two reasons. First, the Informing Science Institute principles of collegial mentoring and free access to research attract many researchers to our journal. Second, education with its inherent communication and informing aspects, is a natural fit within the Informing Science family

Who are the practitioners served by your journal?

Educators, information technologists, and those leveraging technology in education or training.

How do you try to balance the needs of students, researchers, and practitioners?

While the research we publish is fully grounded in the literature and methodologically sound, I also believe that JITE has a very practical outlook, namely, how can we do a better job educating in the IT world.

\section{What characteristics in a submission are your reviewers looking for?}

The manuscript should offer some new insight or idea. The new contribution does not have to be earth shattering, but must be of practical educational value. The data collected has to support the conclusions drawn. The research itself has to follow an established research method and follow it well. Finally, the manuscript has to be grounded in the literature. These components are what makes a manuscript publishable, not just in JITE, but in any high quality journal.

\section{How do you foresee your journal evolving in the future?}

As technology evolves, JITE will continue to evolve. I expect us to maintain our position at the forefront as new technologies continue to be introduced into educational environments.

Does your journal tend to favor positivism versus interpretivism, or quantitative study versus qualitative? Why?

In terms of both research philosophy and methodological approach, we are open-minded. No paper is declined because it used the "wrong" philosophy or approach. We work hard to assign editors and reviewers who are familiar and comfortable with the philosophical and methodological choices a manuscript's authors have taken. Then we expect the authors to deliver a quality paper within the approach they have chosen.

\section{How did you become interested in informing science?}

Contact with Eli Cohen and through the I ${ }^{\mathrm{n}}$ SITE conference.

\section{What do you like the most and the least about being an Editor?}

Most of all, I like having the opportunity to mentor colleagues. Even when we send a rejection letter, we typically edit it multiple times to try to give the authors as much helpful insight and as many positive suggestions as possible. I also enjoy reading the manuscripts our authors submit. This is a wonderful way to keep abreast of all that is happening in the field of technology and 
education. If I have to name a least favorite part, I would say the paperwork involved in tracking all our submissions. Thankfully, Betty Boyd, the Institute's Publisher, does a wonderful job of keeping JITE records on track.

Can you give me one example where an article published in your journal may have made a measurable impact in the broader world?

Our site was visited an average of 821 times per day in February 2011, with visitors coming from 120 different countries on six continents. During that time our five most popular articles were on delphi research, concurrent software engineering projects, database security, online learning, and web-based learning. All of these articles had more than 450 visitors each in just that one month. Given that as human beings we all are influenced by the ideas to which we are exposed, I have no doubt that our articles do have impact in the broader world. We have a very broad and deep readership worldwide. Imagine! 821 visits each day. 121 countries each month. This type of readership would never have been possible without both the Internet and the Informing Science policy of free access to research.

\section{Interdisciplinary Journal of E-Learning and Learning Objects - http://ijello.orgl}

The Interdisciplinary Journal of E-Learning and Learning Objects (2010) (IJELLO) describes its mission as publishing on the developments in E-Learning and Learning Objects. IJELLO is an interdisciplinary forum that publishes articles on theory, practice, innovation and research. IJELLO assists those who submit articles with timely constructive feedback. IJELLO strives to be the most authoritative on E-Learning and Learning Objects.

\section{Key Statistics}

IJELLO was founded in 2005. Since its inception through 2009, it published 85 articles, submitted by 189 authors from 82 institutions.

Key statistics relating to authorship and international contributions are presented in Table 5 and Figure 7 (see Appendix for explanation of data collection for tables 3-9 and Figures 5-11).

Table 5. Frequently published authors and institutions:

Publishing in Journal of E-Learning and Learning Objects

\begin{tabular}{|l|c|c|}
\hline Most Published Author & Country & Number \\
\hline Nicole A. Buzzetto-More & USA & 4 \\
\hline Robin Kay & CAN & 3 \\
\hline Liesel Knaack & CAN & 3 \\
\hline Nitza Geri & ISR & 3 \\
\hline Alex Koohang & USA & 2 \\
\hline Sigal Eden & ISR & 2 \\
\hline Ina Blau & ISR & 2 \\
\hline Orit Naor-Elaiza & ISR & 2 \\
\hline Oskar Casquero & ESP & 2 \\
\hline Javier Portillo & ESP & 2 \\
\hline
\end{tabular}

\begin{tabular}{|l|c|c|}
\hline Most Published Institution & Country & Number \\
\hline Open University Of Israel & ISR & 10 \\
\hline University of Maryland & USA & 4 \\
\hline University of Ontario & CAN & 4 \\
\hline University of Wisconsin & USA & 4 \\
\hline University of Alcalá & ESP & 3 \\
\hline $\begin{array}{l}\text { University of the Basque } \\
\text { Country }\end{array}$ & ESP & 3 \\
\hline Agder University College & NOR & 2 \\
\hline Athabasca University & CAN & 2 \\
\hline Bogazici University & TUR & 2 \\
\hline Çukurova University & TUR & 2 \\
\hline
\end{tabular}




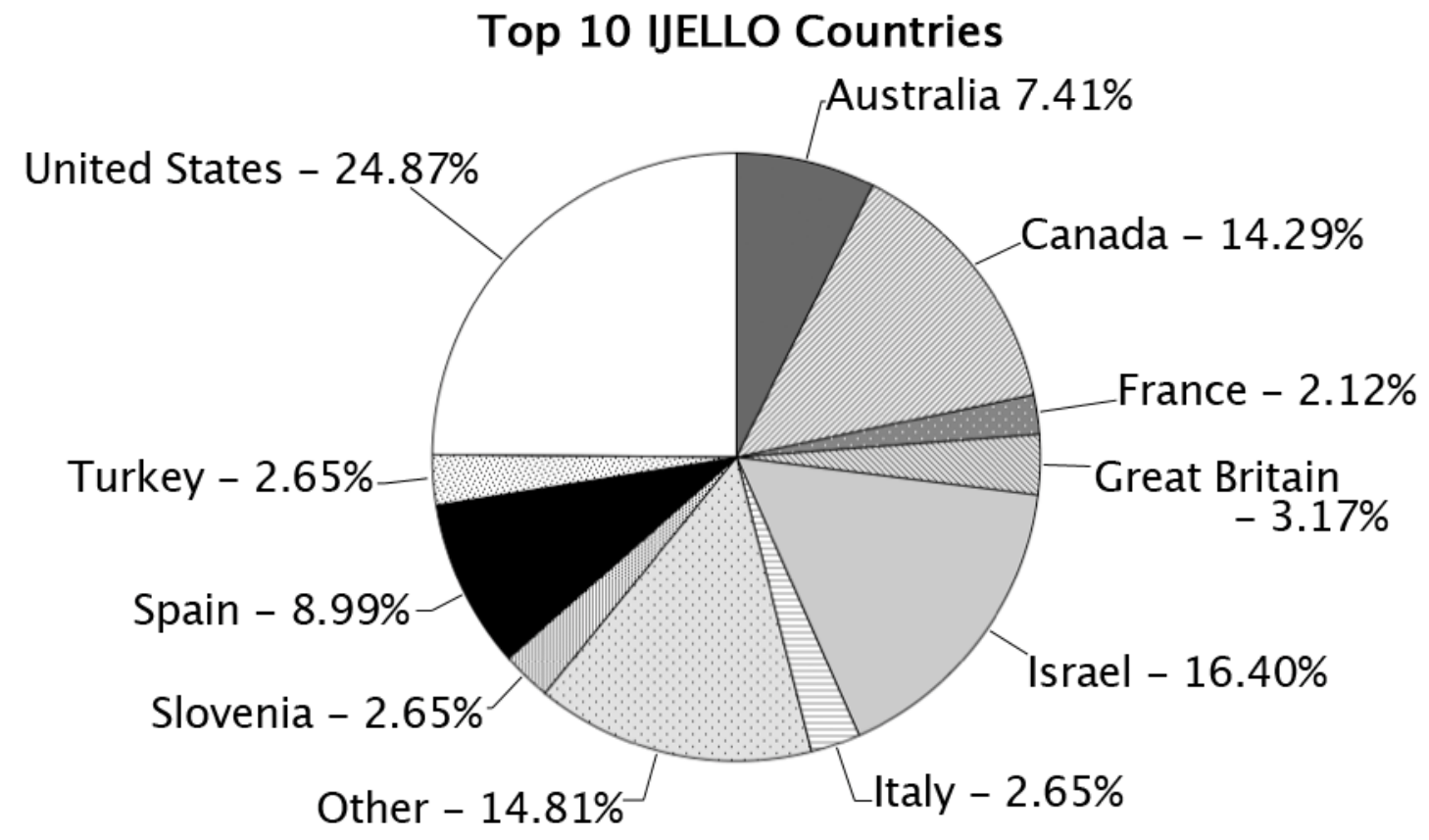

Figure 7 Represents the percentage of articles with authors representing various countries in IJELLO through 2009

\section{An Interview with Alex Koohang, Editor-In-Chief of IJELLO}

Can you tell me about the history of the journal?

It happened back in 2004. In a conference with Eli Cohen in Eastern Europe, he approached me and asked me to come up with the journal.

What are your main aspirations for the journal?

To create a forum for researchers to publish and collaborate more freely.

What readership is the journal serving?

From an author perspective, it is more international than domestic (U.S.), however, there are more reader hits from the US.

What areas of research within your journal do you feel to be the most promising?

The practical areas, because this area is so new that people are coming and asking how it can be used. An example of a practical area would be how to create sound learning objects and using them in a practical setting, and examining it empirically for its efficacy.

Why are certain areas of informing science poorly understood or under recognized?

The transdiscipline part of informing science still requires a lot of work from the community of practice and the community of scholars. The goal is to bring scholars from various disciplines to cooperate and collaborate with each other.

Where does this journal sit within the informing science transdiscipline?

This journal is mainly for practitioners in various disciplines using IT to solve problems. 
Are there any disadvantages to being a journal within the informing science transdiscipline?

No, I always look for improvement, though. This journal follows the essence of informing science.

Who are the practitioners served by your journal?

A professor from any field, or a practitioner from any field, that is using IT to inform his or her audience.

How do you try to balance the needs of students, researchers, and practitioners?

That's tough and perhaps a loaded question. When I receive a paper, I screen it first and then sent it to be reviewed. The review process is a mentoring process. We often mentor the author if needed, but each case is different. We are hoping that once we publish a paper it is beneficial for those who read it.

What characteristics in a submission are your reviewers looking for?

We don't want reviewers to look for reasons to reject papers; rather we want our reviewers to find ways to mentor authors to improve their papers (even if they ultimately can't be published by us).

How do you foresee your journal evolving in the future?

We are going to adapt and use the new technologies as they become available. So, the submission process may not change, but the technologies we are using within our informing systems may change. I hope to see the journal will expand its readership.

Does your journal tend to favor positivism versus interpretivism, or quantitative study versus qualitative? Why?

No, because we are a transdiscipline journal. My rule is that if the paper is good, we will be open minded as to the approach. It is the overall goodness that matters, not that we favor just authors who do a particular method of research.

How did you become interested in informing science?

I was one of the original supporters of the concept - we call it Cohen's Informing Science model. So, I have continued to contribute to the organization in any way I can.

What do you like the most and the least about being an Editor?

I like that I get to read the papers first. And, I like to mentor other authors. I dislike when reviewers commit to reviewing papers, but do not deliver. We understand this is not a paid commitment, but nonetheless we rely on reviewers' help to make a strong journal.

Can you give me one example where an article published in your journal may have made a measurable impact in the broader world?

I wouldn't want to favor one article over another. But, I will say that I have seen many examples of readers or other authors using our articles to support their own research and practice, and that is truly exciting.

\section{Interdisciplinary Journal of Information, Knowledge, and Management - http:/lijikm.orgl}

The mission of the Interdisciplinary Journal of Information, Knowledge, and Management (IJIKM) (2010) is to publish on topics related to the use of information and technology. 


\section{Key Statistics}

IJIKM was founded in 2005. Since its inception through 2009, it published 37 articles, submitted by 78 authors from 43 institutions.

Key statistics relating to authorship and international contributions are presented in Table 6 and Figure 8 (see Appendix for explanation of data collection for tables 3-9 and Figures 5-11).

Table 6. Frequently published authors and institutions: Publishing in Interdisciplinary Journal of Information, Knowledge, and Management

\begin{tabular}{|l|c|c|l|c|c|}
\hline Most Published Author & Country & Number & Most Published Institution & Country & Number \\
\hline Andries Barnard & ZAF & 2 & University of Ljubljana & SVN & 4 \\
\hline John A. Van der Poll & ZAF & 2 & University of South Africa & ZAF & 3 \\
\hline Mojca Indihar Sternberger & SVN & 2 & $\begin{array}{l}\text { Karol Adamiecki University of } \\
\text { Economics }\end{array}$ & POL & 2 \\
\hline Jurij Jaklic & SVN & 2 & Southern Illinois University & USA & 2 \\
\hline Celina M. Olszak & POL & 2 & & & \\
\hline Ewa Ziemba & POL & 2 & &
\end{tabular}

\section{Top 10 IJIKM Countries}

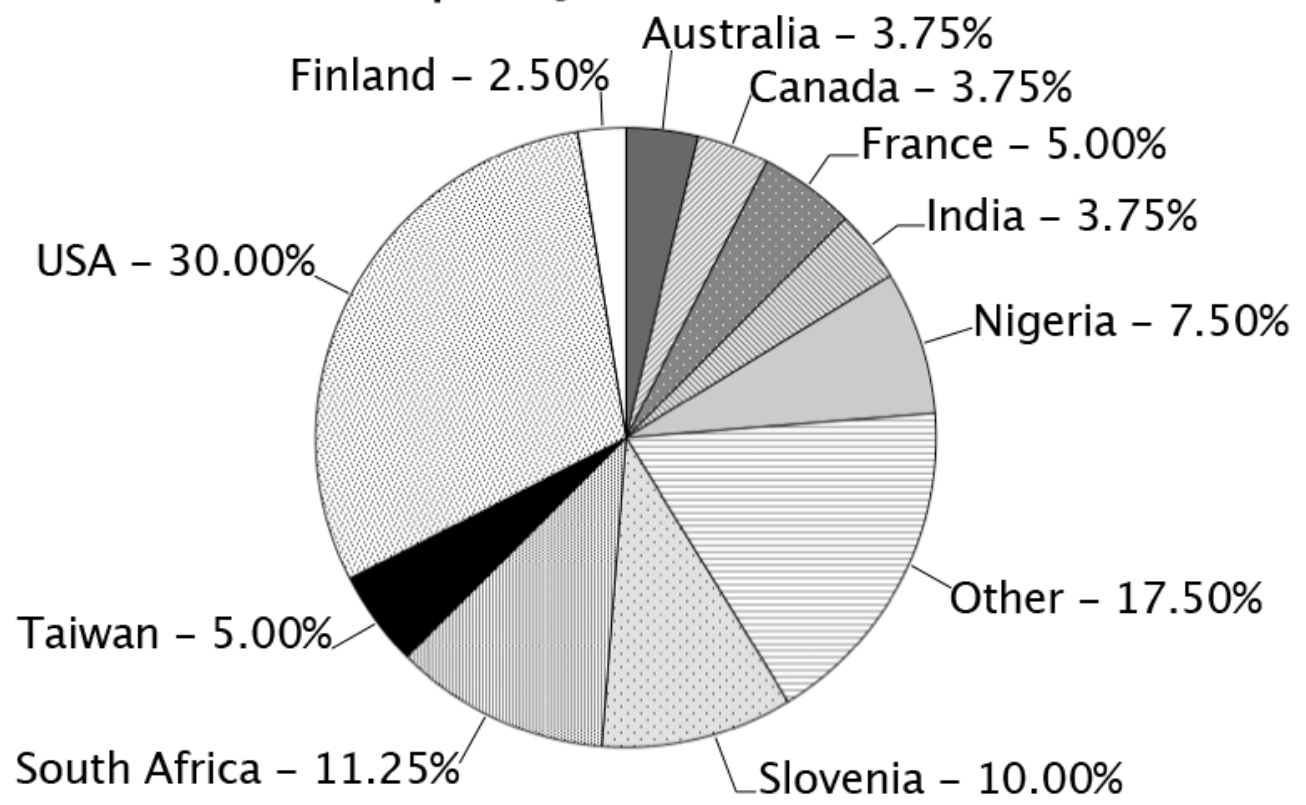

Figure 8 Represents the percentage of articles with authors representing various countries in IJIKM through 2009

\section{An Interview with Eli Cohen, Acting Editor-In-Chief of IJIKM}

\section{What is your position with the Informing Science Institute?}

Executive Director, Managing Editor of all of the Journals, Acting Editor In Chief of The Interdisciplinary Journal of Information, Knowledge and Management. [Since this interview, Raymond Chiong has accepted the position of Editor-in-Chief for IJIKM.] 


\section{Can you tell me about the history of the Institute?}

The idea of informing science as a transdiscipline began years ago. The first thing we did was arrange to have conference tracks at other International conferences, starting with a Finnish Instructional Technology conference, and then another one in Venezuela. Later I was teaching annually in Poland, and a colleague of mine suggested I hold a conference in Krakow, and we decided to hold the first $\mathrm{I}^{\mathrm{n}} \mathrm{SITE}$ conference. Before we held the conference, we created the journal Informing Science to grow interest and legitimacy in the new transdiscipline. Since then we have had ten annual international conferences.

\section{What are your main aspirations for the Institute?}

Our first aspiration is to develop a theory of informing science. We have attempted to develop a theory but, to quote Bruce Lee, if you are attempting to look at the moon, don't stop when you see my fingertip pointing at the moon. Several disciplines claim informing science principles as their own and fail to see how what they do connects to the larger picture.

The second aspiration is to be what a professional Institute should be and to avoid the mistakes other Institutes make. This is why we follow a scientific, non-commercial approach and make our journals and books available online, free of charge. We make this knowledge of Informing Science research available free to all colleagues: members and non-members alike.

A third aspiration is to provide an environment where colleagues can and do mentor colleagues. We actively discourage cliques and encourage collaboration by all participants.

A fourth aspiration is to continue to develop our diverse and international representation. This includes both diversity across geography, but also diversity across departments and disciplines. At one conference, we had a participant thank us for having the conference because, he said, he had been working on a problem and thought he was alone in working on it, and that without this conference, he would never have met someone who was working on the same problem. What's more, he recounted, his new research colleague was from the same university but in a different faculty! Our final aspiration is to help build trust between collaborators, across the globe and across disciplines.

\section{What is the readership and the audience of the Institute?}

Azad Ali compiles our weblogs. In any month, our articles are read (and likely cited) by hundreds of thousands of colleagues.

\section{What research within informing science are you most interested in?}

I am most interested in the research that looks at the psychological and brain science processes, issues of bias as it relates to decision-making, and the brain science aspect that looks at how those biases may be chemically influenced to alter the presentation of what we consider to make decisions. In other words, I am now most interested in the science of irrational.

\section{Why are certain areas of informing science poorly understood or under recognized?}

My biggest suspicion is the "Not invented here" issue; if it is not my field, it is not important.

\section{Who are the practitioners served by your journal?}

My focus is for developing a forum for professors to share knowledge across disciplines. Hopefully, the knowledge exchange and exposure from the cross discipline collaboration trickles from those professors to their audiences, including practitioners and the students who become practitioners. 


\section{What characteristics in a submission are your reviewers looking for?}

Each journal has its own requirements, but the commonality is that submissions should be able to convey their contribution of knowledge to non-experts as well as experts.

\section{How do you foresee the Institute evolving in the future?}

It is going to be taken over by the Fellows. It is going to be given more structure. It will have one leader who is an executive director, and another leader who focuses on advancing the theory, and one person who focuses on the improvements in quality of journals, and conferences, another in membership and development. This way its volunteer leaders can focus on those aspects of development that most fulfills their particular interests.

Does the Institute tend to favor positivism versus interpretivism, or quantitative study versus qualitative? Why?

As a transdiscipline, we have to recognize the epistemology of all the disciplines. If an argument is made cogently, we are happy to publish it and disseminate it. There is truth even in poetry.

What do you like the most and the least about being a role?

I like the most that I designed something for myself that gave me the academic freedom that I did not get in academia. My experience is that academia stifles creativity.

Can you give me one example where an article published in one of the journals may have made a measurable impact in the broader world?

"A Philosophy of Informing Science" (Cohen, 2009a) has had such an impact.

\section{International Journal of Doctoral Studies - http://ijds.org/}

The mission of the International Journal of Doctoral Studies (2010) (IJDS) is to publish articles covering a wide variety of issues in doctoral studies, across any discipline. IJDS welcomes submissions from faculty members and academic administrators actively involved with doctoral programs. Book reviews are also accepted. Submissions to IJDS must focus on issues directly related to doctoral studies.

\section{Key Statistics}

IJDS was founded in 2006. Since its inception through 2009, it published 19 articles, submitted by 34 authors from 20 institutions. Key statistics relating to authorship and international contributions are presented in Table 7 and Figure 9.

Table 7. Frequently published authors and institutions:

Publishing in International Journal of Doctoral Studies

\begin{tabular}{|l|c|c|}
\hline \multicolumn{1}{|c|}{$\begin{array}{c}\text { Most Published } \\
\text { Author }\end{array}$} & Country & Number \\
\hline Azad Ali & USA & 2 \\
\hline Frederick Kohun & USA & 2 \\
\hline
\end{tabular}

\begin{tabular}{|l|c|c|}
\hline \multicolumn{1}{|c|}{ Most Published Institution } & Country & Number \\
\hline Indiana University of Pennsylvania & USA & 2 \\
\hline Robert Morris University & USA & 2 \\
\hline
\end{tabular}




\section{Top 4 IJDS Countries}

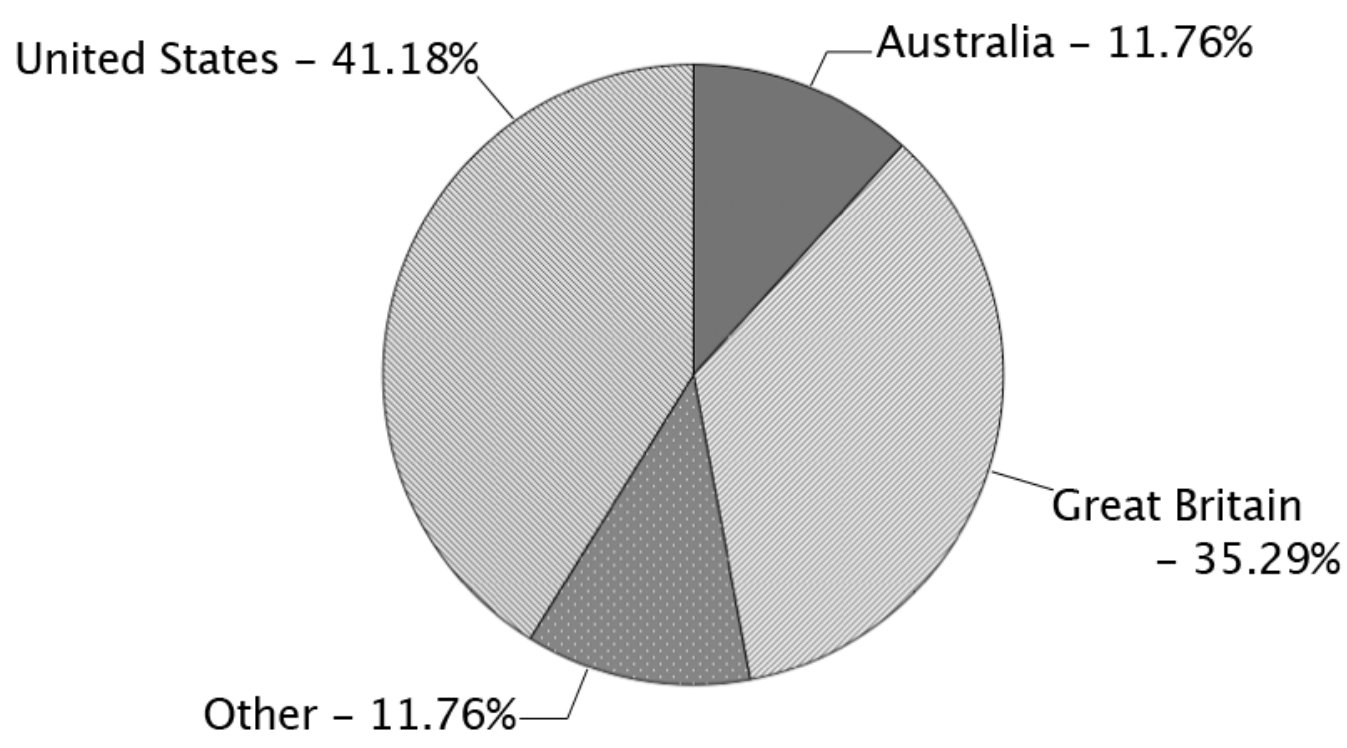

Figure 9 Represents the percentage of articles with authors representing various countries in IJDS through 2009

\section{An Interview with Yair Levy, Editor-In-Chief of IJDS}

\section{Can you tell me about the history of the journal?}

The journal was officially launched when I took it over. Prior to that, it was a work in progress being carried by other members of the institute. During InSITE 2006, I volunteered to take it over and start developing the processes, as well as the infrastructure for it.

\section{What are your main aspirations for the journal?}

One of the biggest areas I hope to accomplish is to extend the reach of this journal beyond management information systems. We are now targeting three major areas: medical, engineering, and law, regarding the experience of doctoral education and skills needed to prepare doctoral programs' graduates.

\section{What readership is the journal serving?}

The area of doctoral student studies is very small and very picky. We are trying to serve doctoral students, those who supervise doctoral students, those who teach doctoral seminars, administrators of doctoral programs, and more recently lawyers, yet the focus is not education, rather all experiences associated with doctoral studies.

\section{What areas of research within informing science do you feel to be the most promising?}

It is so wide that I am not sure we should concentrate on a specific area. I personally find research that address sensitive issues (ethical, misuse, etc) and the personal use of information interesting.

\section{Why are certain areas of informing science poorly understood or under recognized?}

The overall model needs to be better explained. Grandon Gill's (Gill \& Cohen, 2009) book really helps here, but more work needs to be done. Leveraging communication models and diffusion of 
innovation models are an opportunity but the Informing Model has to be differentiated that with Informing the recipient seeks and obtains the information to perform a task.

Where does this journal sit within the informing science transdiscipline?

As doctoral programs are unique, as opposed to undergraduate and master programs, it is by nature transdisciplinary. It sits in the area of doctoral studies and informs on issues within doctoral studies, beyond the educational aspects of doctoral programs.

Are there any disadvantages to being a journal within the informing science transdiscipline?

We are a small group of volunteers without a profit incentive. This limits our infrastructure choices sometimes. If you go to larger publishing portals they sometimes have better funded centralized resources.

How do you try to balance the needs of students, researchers, and practitioners?

$90 \%$ of our reviewers are scholars; about $10 \%$ of our reviewers are practitioners.

\section{What characteristics in a submission are your reviewers looking for?}

It depends on the paper. For research papers, methodology is considered; for opinion papers we look for well-written opinion papers. We are keen to grow our international exposure and increase involvement with fields such as medical, engineering, law, etc as well.

\section{How do you foresee your journal evolving in the future?}

I hope to get more submissions in other fields, especially medical, engineering, social sciences, and law. We also hope to get more editorial participation from such fields of research.

Does your journal tend to favor positivism versus interpretivism, or quantitative study versus qualitative? Why?

We are really very open, with one caveat: the associate editors themselves may have preferences.

How did you become interested in informing science?

The $\mathrm{I}^{\mathrm{n}}$ SITE conference and interacting with the members, and understanding their values.

What do you like the most and the least about being an Editor?

I dislike the amount of work, but I find the ability to see new ideas in many fields very rewarding.

Would you name one study your journal has published that you believe has made a significant impact?

The lawyers have been using two particular studies in lawsuit arguments. One of them is called "The proposed doctoral student bill of rights," (Schniederjans, 2007) and the authors have been called as expert witness in doctoral student lawsuits after reading his paper on our journal.

\section{Journal of Information, Information Technology, and Organizations - http://jiito.orgl}

The purpose of the Journal of Information, Information Technology, and Organizations (2010) (JIITO) is to publish research balancing Information, Information Technology, and Organizations. JITO gives equal treatment to IT and information addressing the need to study them in the context of tasks or processes over appropriate levels of analysis. JIITO encourages submissions that give detailed accounts of information and IT coming from any philosophical perspective that explains information and IT. JITTO also encourages submissions regarding various aspects that have influenced IS research for considerable time. 


\section{Key Statistics}

JIITO was founded in 2006. Since its inception through 2009, it published 32 articles, submitted by 58 authors from 31 institutions. Key statistics relating to authorship and international contributions are presented in Table 8 and Figure 10.

Table 8. Frequently published authors and institutions:

Publishing in Journal of Information, Information Technology, and Organizations

\begin{tabular}{|l|c|c|}
\hline $\begin{array}{c}\text { Most Published Au- } \\
\text { thor }\end{array}$ & Country & Number \\
\hline Bob Travica & CAN & 3 \\
\hline James Lawler & USA & 3 \\
\hline Anthony Joseph & USA & 3 \\
\hline Pascale Vandepeutte & BEL & 2 \\
\hline Lorne Olfman & USA & 2 \\
\hline
\end{tabular}

\begin{tabular}{|l|c|c|}
\hline \multicolumn{1}{|c|}{ Most Published Institution } & Country & Number \\
\hline University of Manitoba & CAN & 4 \\
\hline Pace University & USA & 3 \\
\hline Claremont Graduate University & USA & 2 \\
\hline Nanyang Technological University & SGP & 2 \\
\hline $\begin{array}{l}\text { Norwegian University of Science } \\
\text { and Technology }\end{array}$ & NOR & 2 \\
\hline University of Cape Town & ZAF & 2 \\
\hline University of Mons-Hainaut & BEL & 2 \\
\hline
\end{tabular}

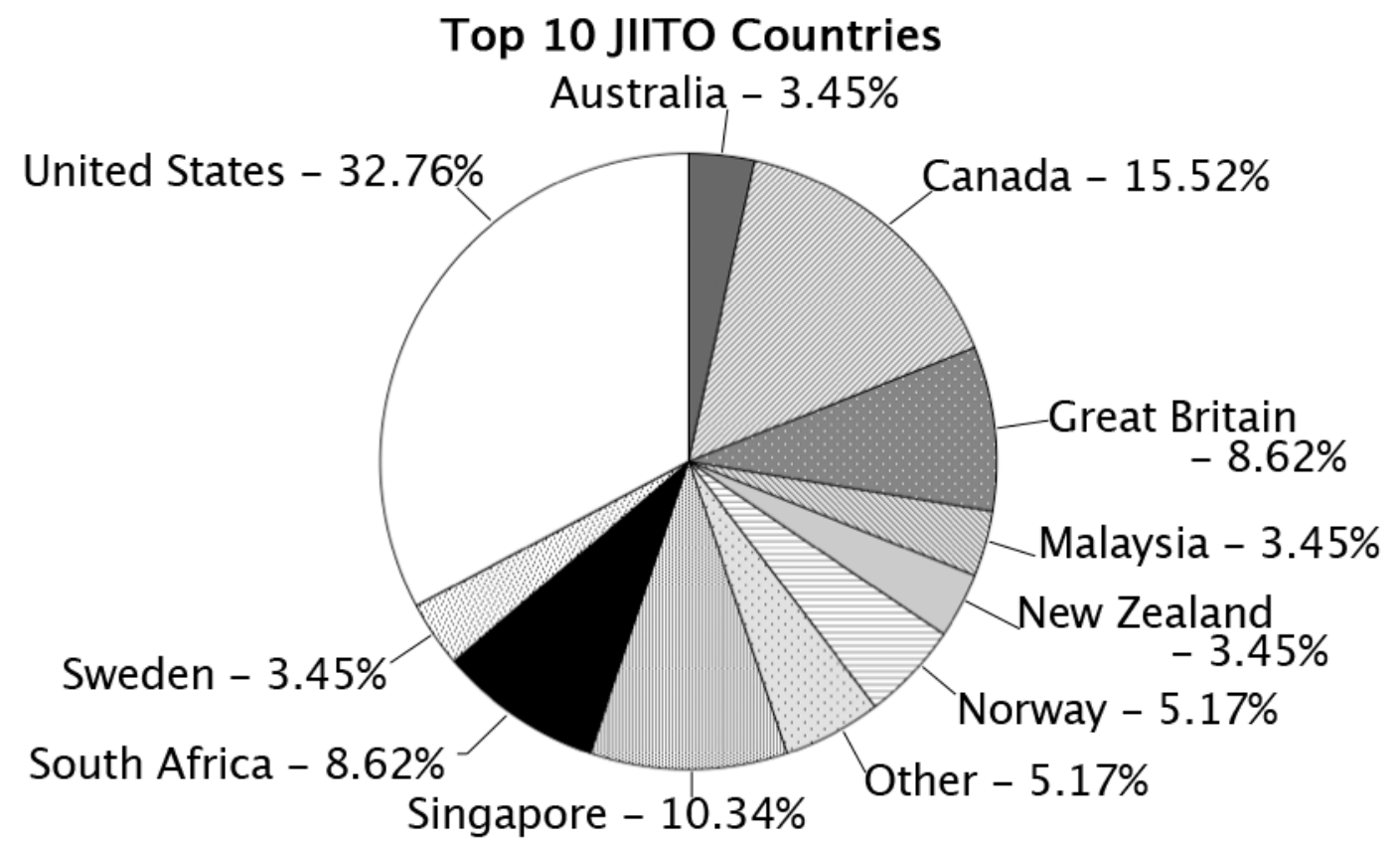

Figure 10 Represents the percentage of articles with authors representing various countries in JIITO through 2009

\section{An Interview with Bob Travica, Editor-In-Chief of JIITO}

\section{Can you tell me about the history of the journal?}

I was at my first $\mathrm{I}^{\mathrm{n}}$ SITE conference in 2005, and Eli Cohen and asked me if I would do some additional work for the community. JITTO was the result. 


\section{What are your main aspirations for the journal?}

That we offer a model that allows an author to publish good research without being manipulated by the commercial publishing establishment.

\section{What readership is the journal serving?}

I don't know. First it was Eli Cohen's I ${ }^{\mathrm{n}} \mathrm{SITE}$ crowd. I have been pushing for more objective metrics. We have made improvements in the last two years, but we can do more to identify our readership.

\section{What areas of research within informing science do you feel to be the most promising?}

I believe that we have a deep division between the information systems field and information related disciplines. We have an opportunity to bridge that gap. Likewise, we need to leverage the communications discipline. We also need to consider organizational theory.

Why are certain areas of informing science poorly understood or under recognized?

I think that informing science is not well known outside of its own community. And the informing science community itself is somewhat fuzzy. Membership in the ISI changes from conference to conference, and outside of that ISI community, few folks are aware of informing science.

There have been many attempts to carve out a new niche in the study of information, and many of them have been transdiscipline, such as the Social Informatics approach.

\section{Where does this journal sit within the informing science transdiscipline?}

I am trying to get those folks focused on technology and the folks focused on information and the folks focused on organization together. And, we cannot forget communication either.

Are there any disadvantages to being a journal within the informing science transdiscipline?

The disadvantage is that we are not established with a level of prestige warranted by the inclusion in the indices of the major academic databases.

How do you try to balance the needs of students, researchers, and practitioners?

We don't.

\section{What characteristics in a submission are your reviewers looking for?}

As the title indicates, we have an integrationist approach. We are trying to get the authors to think about both the information and the technology aspects.

\section{How do you foresee your journal evolving in the future?}

We need to focus on communications beyond just the Shannon and Weaver model, which may in fact be outdated. We need to have more of dialog, not just push our own ideas.

Does your journal tend to favor positivism versus interpretivism, or quantitative study versus qualitative? Why?

All of the above. There is no discriminatory approach at all.

\section{How did you become interested in informing science?}

My interest was in the transdiscipline, although I am still not exactly sure what that means. I am also interested in the volunteer aspect and open publishing model. 
What do you like the most and the least about being an Editor?

The most rewarding part is after working with an author to help him or her improve an article they acknowledge that you have indeed helped them. In contrast, it can be frustrating when some of our journal staff, as volunteers, do not always follow through.

\section{Issues in Informing Science and Information Technology Journal - http://iisit.orgl \\ The purpose of the Issues in Informing Science and Information Technology journal (2010) (II- SIT) is to share knowledge across fields that use information technology. The articles in IISIT provide best practices on how to inform clients using IT and IT research.}

\section{Key Statistics}

IISIT was founded in 2004. Since its inception through 2009, it published 392 articles, submitted by 542 authors from 226 institutions. Key statistics relating to authorship and international contributions are presented in Table 9 and Figure 11.

Table 9. Frequently published authors and institutions:

Publishing in Issues in Informing Science and Information Technology Journal

\begin{tabular}{|l|c|c|}
\hline Most Published Author & Country & Number \\
\hline Azad Ali & USA & 9 \\
\hline Samuel Sambasivam & USA & 8 \\
\hline G. A. Aderounmu & NGA & 7 \\
\hline Frederick Kohun & USA & 6 \\
\hline Raafat George Saade & CAN & 6 \\
\hline Bill Davey & AUS & 6 \\
\hline M. O. Adigun & ZAF & 6 \\
\hline Dimitar Christozov & BGR & 6 \\
\hline Robert Joseph Skovira & USA & 5 \\
\hline Antonio Cartelli & ITA & 5 \\
\hline
\end{tabular}

\begin{tabular}{|l|c|c|}
\hline \multicolumn{1}{|c|}{ Most Published Institution } & Country & Number \\
\hline Victoria University & AUS & 19 \\
\hline Obafemi Awolowo University & NGA & 12 \\
\hline RMIT University & AUS & 9 \\
\hline Robert Morris University & USA & 9 \\
\hline Azusa Pacific University & USA & 8 \\
\hline California State University & USA & 8 \\
\hline Curtin University of Technology & AUS & 8 \\
\hline Griffin University & AUS & 8 \\
\hline Queensland University of Technology & AUS & 8 \\
\hline University of Southern Queensland & AUS & 8 \\
\hline
\end{tabular}

\section{Top 10 IISIT Countries}

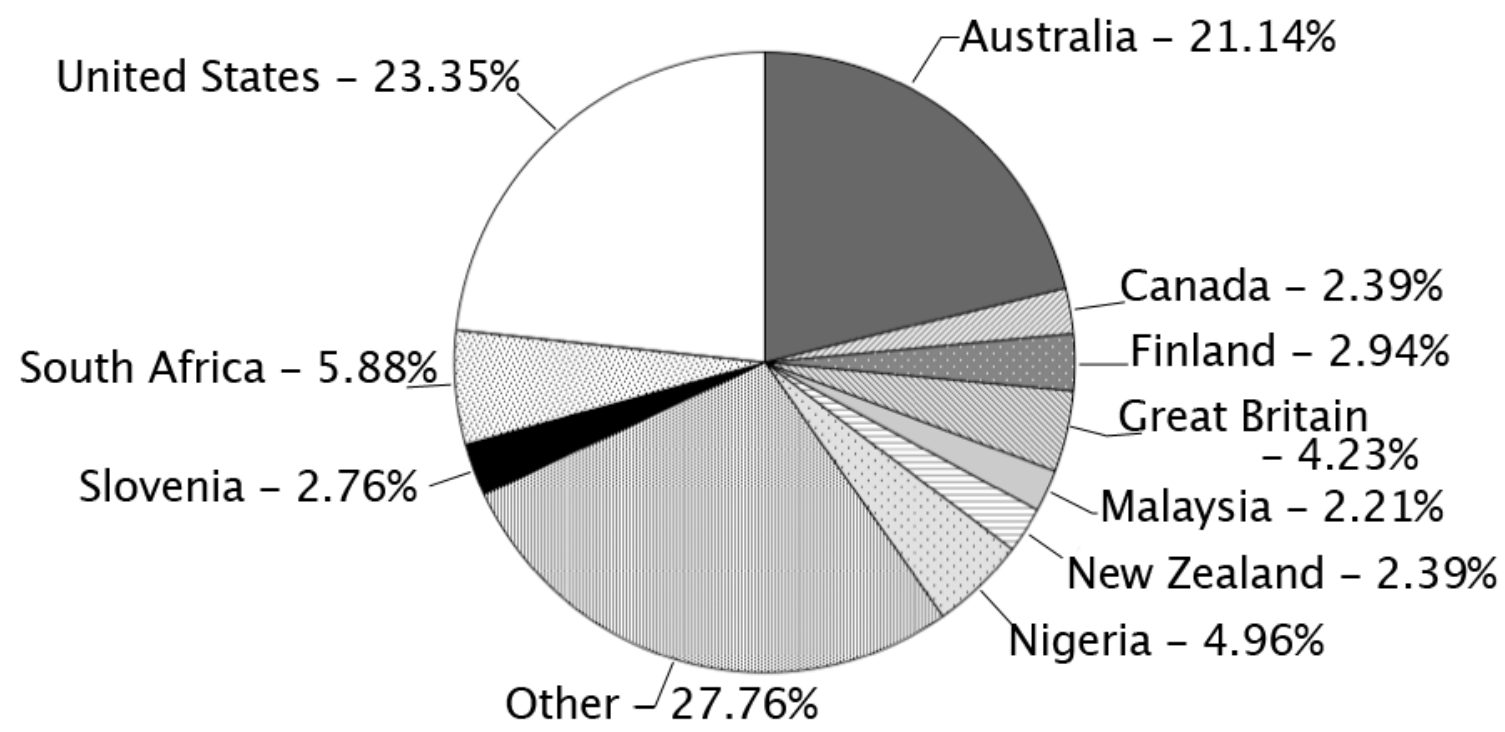

Figure 11 Represents the percentage of articles with authors representing various countries in IISIT through 2009 


\section{Informing Faculty - http://lnformingFaculty.org}

The mission of the Informing Faculty journal is to provide discussion cases that address the challenges faced by faculty participating in higher education (Gill, n.d.). During its first (and only) year operating as a journal, it published 10 case studies - all but one of which was developed for workshops hosted by the Center for $21^{\text {st }}$ Century Teaching Excellence at the University of South Florida. The combination of publishing discussion cases (rather than research cases) and focusing on an area where such cases were not routinely used (higher education) proved to be too great a barrier to potential authors. So, in the absence of sufficient submissions, the journal has since transitioned into a repository in 2007, available to publish such cases should they be developed.

\section{All Published Articles Searchable Archive}

The institute also provides an "all published articles" searchable archive at http://ISjournals.org as another distinct channel to make it easier for its clientele to receive the information that is relevant to them in a resonate way. This list also is designed to encourage search engines to produce search results for ISI published articles as well.

\section{Conferences of the ISI}

The ISI has put on a number of academic conferences. Cohen (2009a) identified that face-to-face communication helps foster trust and a sense of the community. Several of the journal editor-inchiefs the author interviewed for this paper credit the channel of conferences with being the catalyst that sparked their interest in informing science and the Institute.

Recent conferences have included the following:

- $\quad \mathrm{I}^{\mathrm{n}}$ SITE 2011 - Novi Sad, Serbia

- $\mathrm{I}^{\mathrm{n}} \mathrm{SITE} 2010$ - Cassino, Italy

- $\quad$ I $^{\mathrm{n}}$ SITE 2009 - Macon, Georgia, USA

- $\quad$ I $^{\mathrm{n}}$ SITE 2008 - Varna, Bulgaria

- $\quad$ I $^{\mathrm{n}} \mathrm{SITE} 2007$ - Ljubljana, Slovenia

- $\quad \mathrm{I}^{\mathrm{n}}$ SITE 2006 - Greater Manchester, England

- $\quad \mathrm{I}^{\mathrm{n}} \mathrm{SITE} 2005$ - Flagstaff, Arizona, USA

- $\quad$ I $^{\mathrm{n}}$ SITE 2004 - Rockhampton, Australia

- $\quad \mathrm{I}^{\mathrm{n}} \mathrm{SITE} 2003$ - Pori, Finland

- $\quad \mathrm{I}^{\mathrm{n}}$ SITE 2002 - Cork, Ireland

- $\quad \mathrm{I}^{\mathrm{n}} \mathrm{SITE} 2001$ - Krakow, Poland

At these conferences, a number of papers are presented and numerous discussion panels are held. The proceedings of these conferences can be found at http://www.informingscience.org/conferences.php

As shown on the site for the 2011 conference http://2011.informingscience.org/, the conferences currently include four primary tracks:

- In SITE: Connect consists of study in various locations on the transmission of information across time and across space. Connect focuses on the interrelationship between context (historical forces and culture) and information and knowledge transfer.

- $I^{n}$ SITE: Inform solicits papers in any area that explores issues in effectively and efficiently informing clients through IT (information technology).

- I'SITE: TeachIT focuses on research topics related to teaching IT, including curricular issues, capstone courses, pedagogy, and emerging topics in IT. 
- $I^{n}$ SITE: TeLE focuses on research topics related to using IT to teach. For example, these topics include e-Learning, m-Learning, making classroom teaching more effective, and distance learning.

\section{Books and Other Publications Published by the ISI}

The Informing Science Press publishes books related to informing science areas of interest. Such books provide researchers with the opportunity to develop a theme in greater depth than is possible with an article, or to bring together a collection of important articles relating to common topic. Most of the books published by the ISI have been about IT Education and Instructional Technology related topics. However, there have also been some books about informing science itself, as well books about education, e-learning, informing theory, and other areas. Table 10 lists the most frequent subjects covered by the books and collections of articles.

Table 10. Most frequently addressed subject for articles included in the books.

\begin{tabular}{|l|r|}
\hline \multicolumn{1}{|c|}{ Book Subject } & Number \\
\hline Education & 15 \\
\hline e-learning & 13 \\
\hline Informing Theory & 12 \\
\hline Applied IS/IT & 11 \\
\hline Knowledge Objects & 6 \\
\hline Knowledge Management & 4 \\
\hline Multimedia & 3 \\
\hline Internationalization & 1 \\
\hline Open-Source & 1 \\
\hline
\end{tabular}

\section{Outreach Channels}

Ironically, it may be that informing science gains greatest credibility when it is mentioned in journals not dedicated to informing science, namely discipline specific journals. This is a theme touched upon in Gill and Bhattacherjee (2009b), where those same authors also stated that academic research in general is failing to engage information systems practitioners in business. Although the ISI may be doing a good job in engaging academics from multiple disciplines, that does not necessarily translate into its research resonating with practitioners from different disciplines.

Academic outreach in channels outside the ISI may be the logical place to start to provide outreach value while simultaneously gaining third party credibility. We would define third party credibility as when someone other than your own members recognizes or mentions the work or philosophy of informing science. To use a metaphor, there is usually a different reaction if the owner of a restaurant says the food is good than if a third party food critic says it is good. The ISI needs some third party critics edifying its mission rather than just the members or channels within the ISI doing so. Fortunately, there is progress being made in these areas. Recently, informing science has been a central theme of two MISQ articles by Gill \& Bhattacherjee (2009a, 2009c) and an ICIS panel (Myers, Baskerville, Gill, \& Ramiller, 2010). In 2011, an engineering symposium specifically examining informing science's application to engineering disciplines was organized by the International Institute of Informatics and Systems, an organization not affiliated with the ISI. As more non-ISI informing science conferences, panels, and articles become available, the visibility and credibility of informing science will certainly grow. 
Going beyond academic channels, some thought should be given to how to better engage professionals and win their participation as members of the ISI or at least as practitioners aware of informing science approaches to building informing systems with practical applications.

\section{Conclusions}

To recap, the Informing Science Institute has published approximately 1,000 articles by over 1,000 authors from over 500 universities with impressive international participation. This accomplishment as a research outlet was achieved by using the philosophical principles and design guidelines of informing science to create the informing system that is the Institute. In effect, the Institute has effectively been 'practicing' what it is 'preaching'.

One of the foremost informing science principles the ISI has employed is addressing the need to inform its clients with rigor, relevance, and resonance. The ISI achieves relevance by publishing articles around a common theme: research that examines questions relating to informing. The ISI achieves rigor through a peer review process that is led by experienced researchers who are committed to researchers mentoring researchers. The ISI achieves resonance by providing various communication channels that are already known to resonate among its clients (who are largely academic researchers), including peer reviewed academic journals, repackaging articles across its journals into books that examine specific themes, holding face-to-face international conferences and other outreach activities. By embracing an open access model where the journals do not charge for publication nor downloading published articles (and books are made available online without charge through Google Books), the ISI has done a particularly good job at achieving international participation in the research publication process, especially compared to many traditional academic journals affiliated with for-profit publishing entities. However, the other channels of the ISI also provide their own unique contribution to the informing system. Trust is always an issue with recipients of messages being willing to receive messages and can even be an issue with senders of messages being willing to send messages. The conferences the ISI organizes are a channel designed to facilitate trust, relationships, and participation among the membership of the ISI.

By following the principles of the informing science philosophy in creating its own informing system, the ISI has with some noteworthy success been "eating its own dog-food", to borrow a phrase from Microsoft. In the future, the ISI's goal must expand beyond its own membership, however. It must become a recognized and respected participant in existing informing systems that serve academia. Through such recognition, researchers can be rewarded (and certainly not punished) for choosing to adopt a transdisciplinary focus. Perhaps the best way to accomplish this is through publishing articles about informing science in traditional, discipline-specific journals, citing ISI articles about informing science while doing so.

Another area where the ISI may want to consider expanding is in the area on non-academic clients, such as practitioners in business and government. The problem with academic research published in academic journals is that it can fall into the trap of becoming inward focusing. Particularly in U.S., this has become rule rather than the exception in many areas (Gill \& Bhattercherjee, $2009 b$ ). Just being transdisciplinary does not protect its journals from such a tendency. As evidenced by the interviews with the Editors in Chiefs of the various ISI journals, there is a real danger that practice will come to be ignored if engagement is not actively sought. Perhaps in the future the ISI could become transoccupational as well as transdisciplinary. After all, if disciplinary silos can cause research myopia, occupational silos can as well. At the end of the day it is the job of the researcher to create knowledge and solve problems. Should academia ignore the researchers in industry and should the researchers in industry ignore the researchers in academia when they are both trying to solve problems relating to informing? The answer is "of course not." Both academia and practice face complex problems that require leveraging and combining multiple 
approaches. As a start, the ISI may want to increase the ratio of practitioner focused articles in its current journals, or even launch specialty journals specifically intended to resonate with practitioners.

Every challenge is a potential opportunity. So, the opportunities of the ISI for future growth, contribution, and improvement are myriad. The ISI has done a commendable job based on the leadership of its founders and the work of its volunteer army. But, any virtue can be a vice if taken to an extreme. There are many questions that can be raised with respect to the challenges of the future. Has the ISI done too good of a job in avoiding fund raising conflicts of interest? With slightly better infrastructure, outreach evangelist budgeting, and more aggressive marketing of itself and informing science, would informing science have more awareness and acceptance in academia? In an open access model with such large international participation, is there room for papers published that are not in English if qualified editors and reviewers can be found who are fluent in other major languages? Can the ISI use informing science and its experience to 'seed' other institutes dedicated to transdisciplinary research to attack complex problems that are not related to problems of informing but are none the less complex and in need of informing systems?

In speculating about future opportunities, however, it is important not to forget the extraordinary accomplishments of the Informing Science Institute in constructing an informing system to disseminate informing science principles to its large and growing clientele. Across every nearly conceivable dimension - number of ISI members, conference attendance, international representation, the breath of disciplines included and the scope of publications produced - major advances have been made with virtually no external resources. These achievements provide clear evidence that the principles of mentorship, open access, and transdisciplinary perspective common to all ISI activities collectively constitute a powerful system for informing. As long as the commitment of the informing science community to these principles remains steadfast, a continuing stream of contributions to knowledge and growing outside acceptance of informing science seems inevitable.

\section{References}

Cohen, E. (2009a). A philosophy of informing science. In T. G. Gill \& E. Cohen (Eds.), Foundations of Informing Science: 1999-2008 (pp. 767-788). Santa Rosa, CA: Informing Science Press.

Cohen, E. (2009b). Reconceptualizing information systems as a field of the transdiscipline informing science: From ugly duckling to swan. In T. G. Gill \& E. Cohen (Eds.), Foundations of Informing Science: 1999-2008 (pp. 7-19). Santa Rosa, CA: Informing Science Press. (Reprinted from the Journal of Computing and Information Technology, 7(3), 213-219, 1999)

Cole, J. R., \& Cole, S. (1973). Social stratification in science. Chicago: University of Chicago Press.

Dolgin, E. (2009). Online access = more citations. The Scientist. Retrieved from http://www.thescientist.com/blog/display/55437/

Gill, T. G. (2009a). Informing resonance: Beyond rigor and relevance. In T. G. Gill \& E. Cohen (Eds.), Foundations of Informing Science: 1999-2008 (pp. 239-286). Santa Rosa, CA: Informing Science Press.

Gill, T. G. (2009b). Utility and informing. In T. G. Gill \& E. Cohen (Eds.), Foundations of Informing Science: 1999-2008 (pp. 197-238). Santa Rosa, CA: Informing Science Press.

Gill, T. G. (2009c). An Open Letter to the Informing Science Community. Informing Science: the International Journal of an Emerging Transdiscipline, 12, v-x. Retrieved from http://inform.nu/Articles/Vol12/ISJv12pv-xGill.pdf

Gill, T.G. (n.d.). The Informing Science Institute presents Informing Faculty: An international journal of higher education discussion cases. Retrieved August 2, 2010, from http://informingfaculty.org/InformingFacultyAnnouncement.pdf 
Gill, T. G., \& Bhattacherjee, A. (2009a). Whom are we informing: Issues and recommendations for MIS research from an informing sciences perspective. MIS Quarterly, 33(2), 217-235.

Gill, T. G., \& Bhattacherjee, A. (2009b). Informing science at a crossroads: The role of the client. In T. G. Gill \& E. Cohen (Eds.), Foundations of Informing Science: 1999-2008 (pp. 21-55). Santa Rosa, CA: Informing Science Press.

Gill, T. G., \& Bhattacherjee, A. (2009c). Fashion waves versus informing: Response to Baskerville and Myers. MIS Quarterly, 33(4), 667-671.

Gill, T. G. \& Cohen, E. (2009). Introduction to the foundations of Informing Science. In T. G. Gill \& E.Cohen (Eds.), Foundations of Informing Science: 1999-2008 (pp. 1-6). Santa Rosa, CA: Informing Science Press.

Hagstrom W.O. (1965). The scientific community. New York: Basic Books.

Hamermesh, D. S., Johnson, G. E., \& Weisbrod, B. A. (1982). Scholarship, citations and salaries: Economic rewards in economics. Southern Economic Journal, 49, 472-481.

Herb, U. (2010). Sociological implications of scientific publishing: Open access, science, society, democracy, and the digital divide. First Monday, 15(2). Retrieved from http://firstmonday.org/htbin/cgiwrap/bin/ojs/index.php/fm/rt/printerFriendly/2599/2404

Informing Science Institute (ISI). (2011). Who we are. Retrieved January 6, 2011, from. http://informingscience.org/homepage.php

Informing Science: The International Journal of an Emerging Transdiscipline (InformSciJ). (2010). Mission. Retrieved August 2, 2010, from http://inform.nu/mission.html

Interdisciplinary Journal of E-learning and Learning Objects (IJELLO). (2010). Mission. Retrieved August 2, 2010, from http://ijello.org/mission.html

Interdisciplinary Journal of Information, Knowledge, and Management (IJIKM). (2010). Mission. Retrieved August, 2, 2010, from http://ijikm.org/mission.html

International Journal of Doctoral Studies. (IJDS). (2010). Mission. Retrieved August 2, 2010, from http://ijds.org/mission.html

Issues in Informing Science and Information Technology (IISIT). (2010). Mission. Retrieved August 2, 2010, from http://iisit.org/mission.php

Journal of Information, Information Technology, and Organizations (JIITO). (2010). Mission. Retrieved August 2, 2010, from http://jiito.org/mission.html

Journal of Information Technology Education (JITE). (2010). Mission. Retrieved August 2, 2010, from http://jite.org/mission.html

Meadows, A .J. (1974). Communication in science. London, UK: Butterworth.

Myers, M. D.; Baskerville, R. L.; Gill, T. G., \& Ramiller, N. (2010). Setting our research agendas: Institutional ecology, informing sciences, or management fashion theory? ICIS 2010 Proceedings. Paper 4. Retrieved from http://aisel.aisnet.org/icis2010 submissions/4

Schniederjans, M. (2007). A proposed Ph.D. student bill of rights. International Journal of Doctoral Studies, 2, 1-8. Retrieved from http://ijds.org/Volume2/IJDSv2p001-008Schniederjans22.pdf

Shannon, C. E., \& Weaver, W. (1949). The mathematical theory of communication. Urbana, Illinois: The University of Illinois Press.

Zuckerman, H., \& Merton, R. K. (1971). Patterns of evaluation in science: Institutionalization, structure and functions of the referee system. Minerva, 9, 66-100. 


\section{Appendix: Data Collection Process}

1. The research started by examining the existing cataloging database of ISI articles. The cata$\log$ had been updated to a certain date, and needed to be brought current.

2. I then added new articles to the catalog list by going to www.iisit.org (Issues in Informing Science and Information Technology) to a spreadsheet list (articles_local) of Informing Science Institute (ISI) articles. ArticleFileName came from the URL of each individual ISI article on the informing science website.

3. I then updated authors from the new articles to the new list with author IDs assigned after the last author ID number in the original list provided.

4. Institution and department was initially the institution/department provided in an author's most recent publication in the ISI journals. School/College/Faculty was used interchangeably with department in many circumstances, since many institutions would only separate their sections down to School or College, or would describe similar organizational units as a faculty instead of as a department.

5. Authors without enough information for a complete entry were searched on Google, comparing name/picture/background information to ensure that the information found was pertaining to the author (also used to link articles to authors that used multiple names or had a name change.)

6. Departments for each institution were compared to ensure that they would be consistent.

7. Private consultants and developers were listed by their organization and job title, as were University personnel who did not belong to a single department (usually administrative personnel.)

8. Authors from the new articles were cross-referenced with the existing authors and their IDs, updating the author entries to the information provided in the IISIT articles

9. The initial article entries were a single entry with multiple author IDs linked to it.

10. Once the entries were complete, full author entries were added in place of the lone IDs. This created an entry for every instance of ArticleID and AuthorID combination.

11. We then removed duplicated entries in the original author lists and a few in the new IISIT list.

12. The errors/duplicates in the original list provided were due to the author names being based off a nickname (John instead of Jonathan, etc.), foreign names where a middle, last, or first name might be used interchangeably, or due to spaces and punctuation that had accidentally been added (assumed prior to a remove duplicates being done.)

13. Author country was added based on the author's listed institution. Author countries were listed under their ISO 3166-1 alpha-3 codes (three letter codes from the International Organization for Standardization.)

14. Citations counts for each articles was retrieved from Google Scholar searches for each article's title.

15. The remove duplicates function in Excel was used to create unique entries based on what field needed to be measured. (see examples).

16. Pivot charts were used to organize and count the information once the duplicates were removed. 
17. Article country per year had to use all of the unique countries for each article. This meant that an article with two authors from the U.S. and an author from Brazil would contribute 1 U.S. and 1 Brazilian to the entries. The alternative would be splitting the article among the authors, which would not necessarily be any more helpful.

18. Pivot chart data was used to create histograms and pie charts for ISI.

19. Top 10 institutions/authors were made with pivot charts, with the resulting values copied and sorted.

20. I reupdated updated author data with data provided at the time of the articles. This sometimes left departments empty, which was filled based on later entries by the same author at the same institution, or based on other authors at the same institution. Author countries were redone based on the initial institution in the articles.

21. Institutions that were multiple campuses of the same University system (Multiple University of California locations, etc.) were consolidated into single institutions.

22. Data, charts and tables were redone/updated when revised. Data/Information for charts was limited to 2002-2009 in most cases. 2010 data was incomplete for most journals aside from citation data. ISI was also split into each individual ISI journal to be included with the other journal data sets.

\section{Biography}

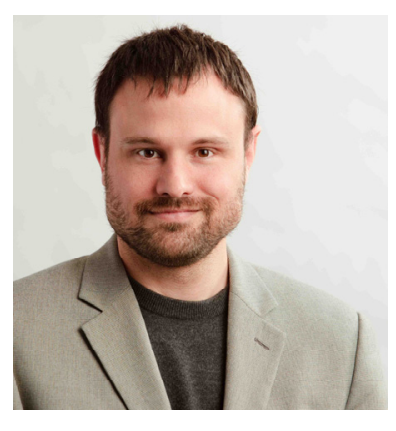

William F. Murphy, Jr. has nearly 20 years of industry experience. Mr. Murphy has held Chief Information Officer Positions at several firms. He has a Masters of Arts in Applied Economics from the University of Central Florida and a Masters of Science in Risk Management Finance from Florida State University, and is currently finishing a $\mathrm{PhD}$ program in Information Systems and Decision Sciences at the University of South Florida College of Business. His personal consultancy researches and develops mobile applications for large companies, and provides confidential merger and acquisition diligence services for intellectual property related acquisitions. 